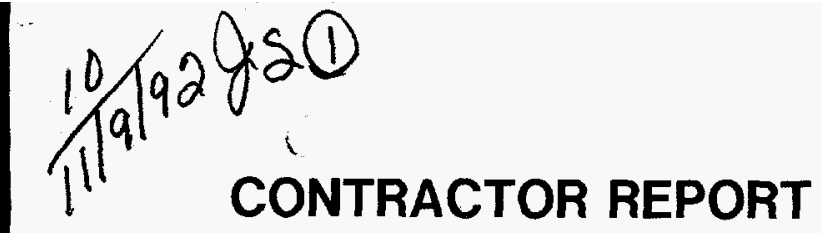

SAND92 -7001

Unlimited Release

UC -275

\title{
Development of a Commercial Photovoltaic Concentrator Module
}

Shabbar T. Saifee, Gus Hutchison

Solar Kinetics, Inc.

10635 King William Drive

Dallas, TX 75220

Frepared by Sandia National Laboratories Albuquerque, New Mexico 87185

and Livermore, California 94550 for the United States Department of Energy

under Contract DE-AC04-76DP00789

Printed September 1992 
Issued by Sandia National Laboratories, operated for the United States Department of Energy by Sandia Corporation.

NOTICE: This report was prepared as an account of work sponsored by an agency of the United States Government. Neither the United States Government nor any agency thereof, nor any of their employees, nor any of their contractors, subcontractors, or their employees, makes any warranty, express or implied, or assumes any legal liability or responsibility for the accuracy, completeness, or usefulness of any information, apparatus, product, or process disclosed, or represents that its use would not infringe privately owned rights. Reference herein to any specific commercial product, process, or service by trade name, trademark, manufacturer, or otherwise, does not necessarily constitute or imply its endorsement, recommendation, or favoring by the United States Government, any agency thereof or any of their contractors or subcontractors. The views and opinions expressed herein do not necessarily state or reflect those of the United States Government, any agency thereof or any of their contractors.

Printed in the United States of America. This report has been reproduced directly from the best available copy.

Available to DOE and DOE contractors from

Office of Scientific and Technical Information

PO Box 62

Oak Ridge, TN 37831

Prices available from (615) 576-8401, FTS 626-8401

Available to the public from

National Technical Information Service

US Department of Commerce

5285 Port Royal Rd

Springfield, VA 22161

NTIS price codes

Printed copy: A04

Microfiche copy: A01 


\subsection{Photovoltaic Cell Assembly Fabrication Operations}

The approach taken was to design, develop, and fabricate all components possible at Solar Kinetics, Inc. (SKI). The objective was to minimize costs in the fabrication and processing of the various components when possible. This helps to establish the fabrication issues and leads to identifying difficulties in the design. Fabrication of most cell assembly and module housing components requires precision sheet metal work. All such components were fabricated using SKI machinery.

The solar cell assembly consists of six components. They include the PV cell, the heat spreader, the bottom contact, the top contact, the SOE, and the SOE mounting tabs. An exploded view of the cell assembly as currently executed shows the various components in Figure 2.1. Each component required fabrication and/or processing prior to assembly.

Solar Cell: The photovoltaic cell used is a $\mathrm{N}+$ on $\mathrm{P} / \mathrm{P}+$ type single-crystalline silicon cell with efficiency varying from $15 \%$ to $19 \%$ at $300 \mathrm{X}\left(264 \mathrm{~kW} / \mathrm{m}^{2}\right)$ and $77{ }^{\circ} \mathrm{F}$. A detailed specification of this PV cell manufactured by the Applied Solar Energy Corporation (ASEC) is included as Appendix A. The solar cells were visually inspected upon receipt. After various soldering tests, the following process was used. The backs were cleaned by wiping with an organic solvent. The cell back was fluxed, and the cell was placed face down on a cool soldering platen. Square solder preforms were cut to fit the area of the back of the cells. The preform was placed on the backside of the cell and the cell was transferred to a hot platen, causing the solder to flow, thus pretinning the cell back. The cell and platen cooled, and the cell was transferred to in-process storage.

Heat Spreader: The material for the heat spreader was received in sheet form. It was 0.060-inch-thick oxygen-free high-conductivity (OFHC) copper. In the first operation, the sheets were loaded onto a CNC turret punch. The control of the punch die stroke was such that the heat- spreader disk was not entirely separated from the sheet. It was sheared all the way around the perimeter, but the punch stroke stopped before the disk separated through the parent sheet. The sheet was taken off the press, and the parts manually separated from the sheet. This was done to prevent potential damage, such as nicking or bending that could occur if the press ejected the parts in the normal manner. The spreaders were manually deburred immediately after removal from the sheet.

The next operation was flattening. A press with a flat ram and platen squeezed the heat spreader to remove any bowing resulting from the stamping operation. Finally, the part was vapor degreased with 1,1,1-Trichloroethane, acid etched in $15 \%$ nitric acid, rinsed, fluxed and pretinned on one side by a similar method as used on the cell. 


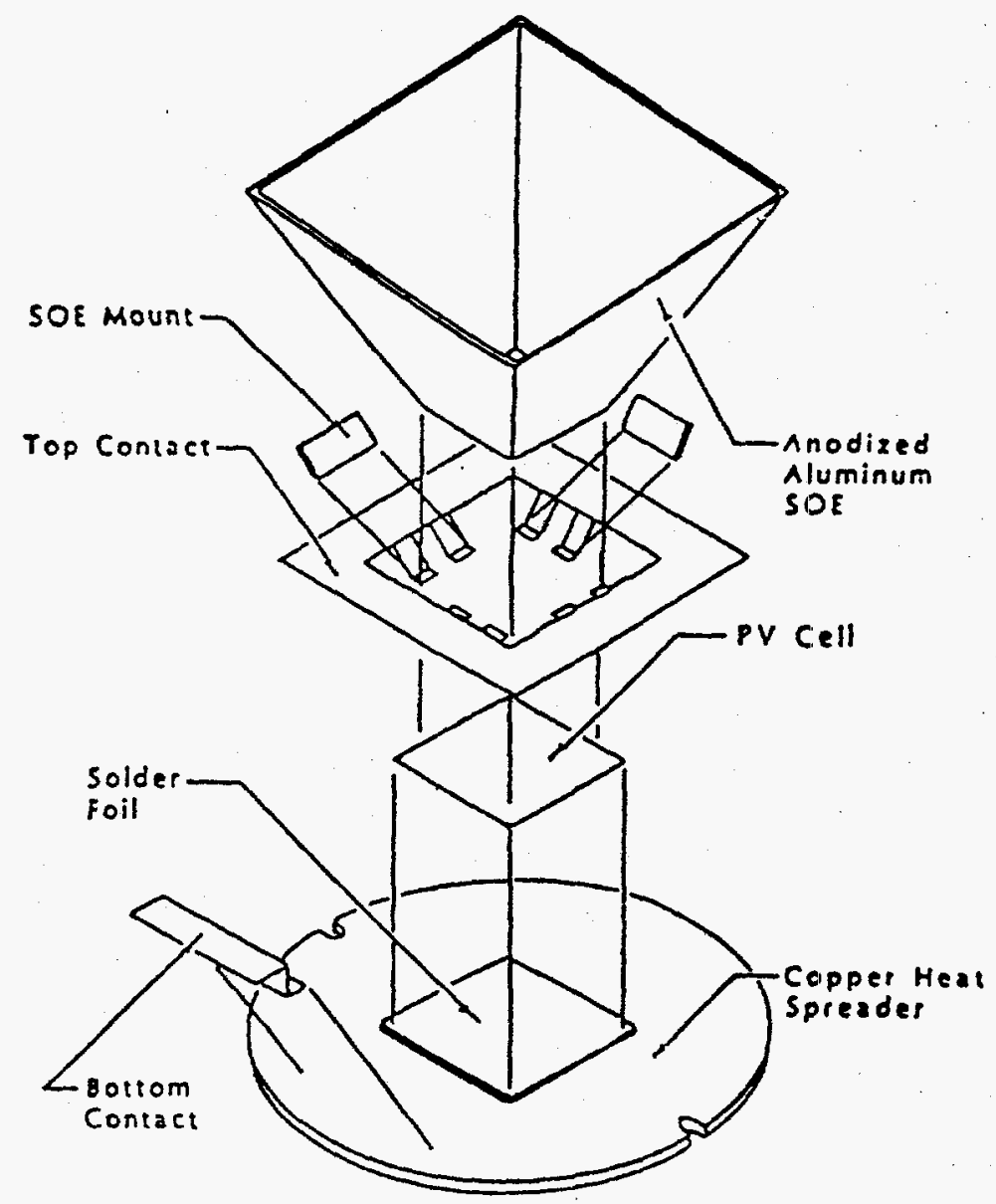

Figure 2.1 Exploded View of Concentrating PV Cell Assembly. 


\section{DISCLAIMER}

Portions of this document may be illegible electronic image products. Images are produced from the best available original document. 
Bottom Contact Tab: The copper used was 0.010-inch-thick, 1-inch wide ribbon of OFHC type. The copper for this component was received as flat coil stock. It was sheared to length and then formed in a custom die set in a single station press. Figure 2.2 is the fabrication drawing of the bottom contact. Next, the part was acid etched, rinsed, fluxed, and pretinned. The first design of the bottom tab had no holes. After soldering, there was a significant voiding due to entrapment of flux gases. Small holes were drilled in the bottom tab to let the flux gases escape. These holes were also useful for visual inspection of the solder flow.

Top Contact: This intricate part was made from sheet stock OFHC copper 0.010 inch in thickness. Fabrication drawing of the top contact is shown in Figure 2.3. In the current operation, a large sheet of copper was taped to a back-up sheet of thin aluminum to serve as a carrier during the punching operation. Next, this assembly was loaded into the CNC turret punch where a series of fine rectangular dies blanked out the interior dimensions of several dozen parts on the same sheet. The center contours of each part were knocked out to allow forming of the contact fingers. A forming tool was in place in the turret punch at one station to form the contact fingers. When the sheets were removed from the turret punch, the individual contacts were simply sheared apart, their contours already complete. A secondary forming tool in a singlestation press was used for final adjustment of the contact fingers to assure uniform height.

The top contacts were acid etched, rinsed, and fluxed. Then the fingers were pretinned. Pretinning is used only where the contact finger tips rest on the cell edges and where the top interconnect attachment tab solders to the cell interconnect strap.

Secondary Optical Element (SOE): The SOE material is delivered pre-polished with a thick clear anodize coating in sheet form with a sheet plastic premask. This chemically polished aluminum is 0.012 inch thick and has average specular reflectivity in the silicon cell response spectrum of 82-84\%. A sketch of the flat pattern of the SOE is shown in Figure 2.4. At SKI, the flat parts for the pyramid final shape were blanked out most of the way on the CNC turret punch. The turret punch press used for the fabrication of the top contact, the heat spreader and the SOE are shown in Figure 2.5. Connecting fingers were left in place to allow a sheet's worth of parts to be removed from the punch as a single piece. The individual pieces were separated by simple shearing of the connecting tabs.

In the current operation, each SOE was bent using custom Delrin bending dies in a small press brake. This polymer tooling was used to avoid marking the polished SOE material through the protective sheet premask. The locking tabs were inserted through the slots and bent over and crimped to finish the assembly. The premask was not removed until the fabrication of the cell assembly and its placement were complete inside the module. The plan was to remove the premasks from all the 24 cell assemblies before the placement of the Fresnel lens parquet, thus eliminating the possibility of contamination of the reflective surface due to handling and ambient dust. 

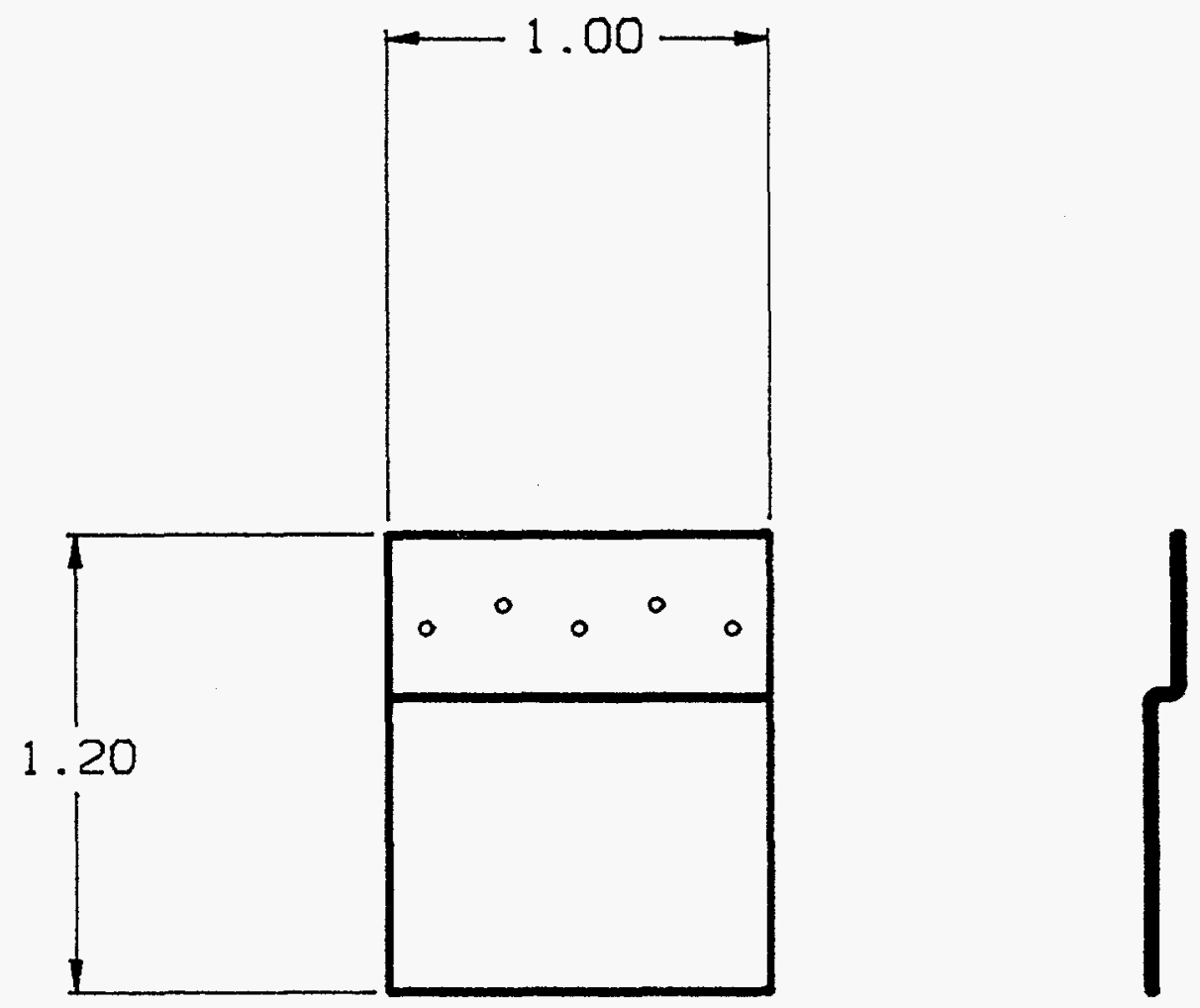

Figure 2.2 Fabrication Drawing of Bottom Contact. 

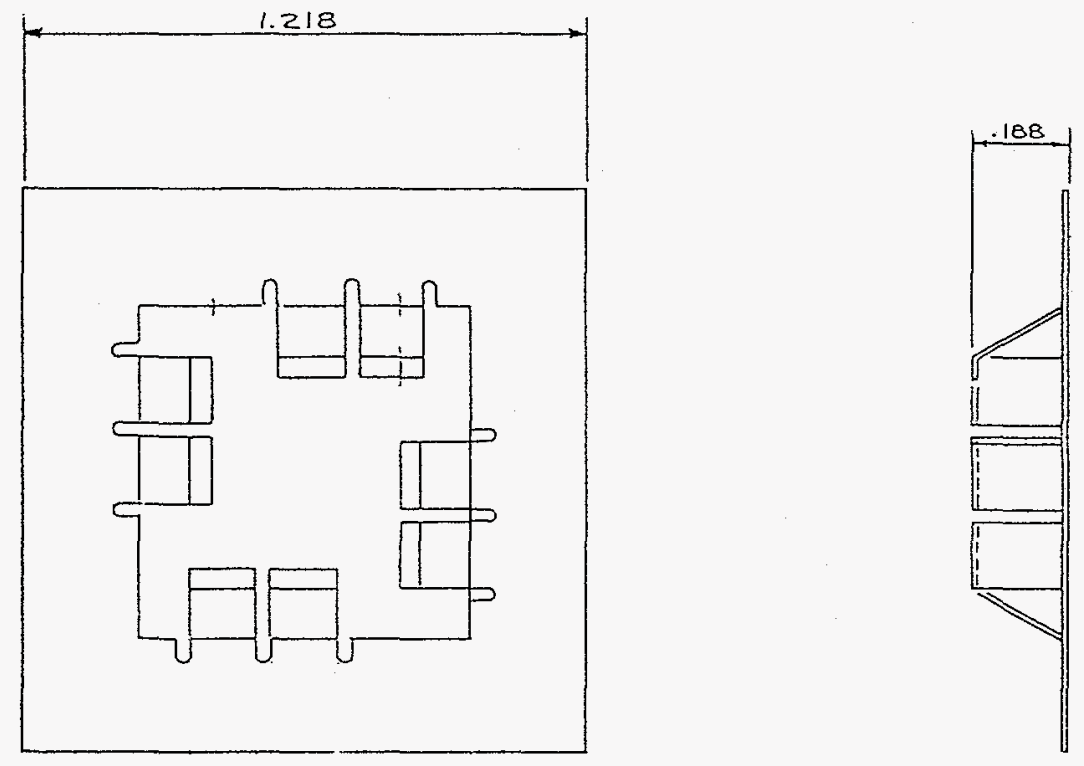

Figure 2.3 Fabrication Drawing of the Top Contact. 


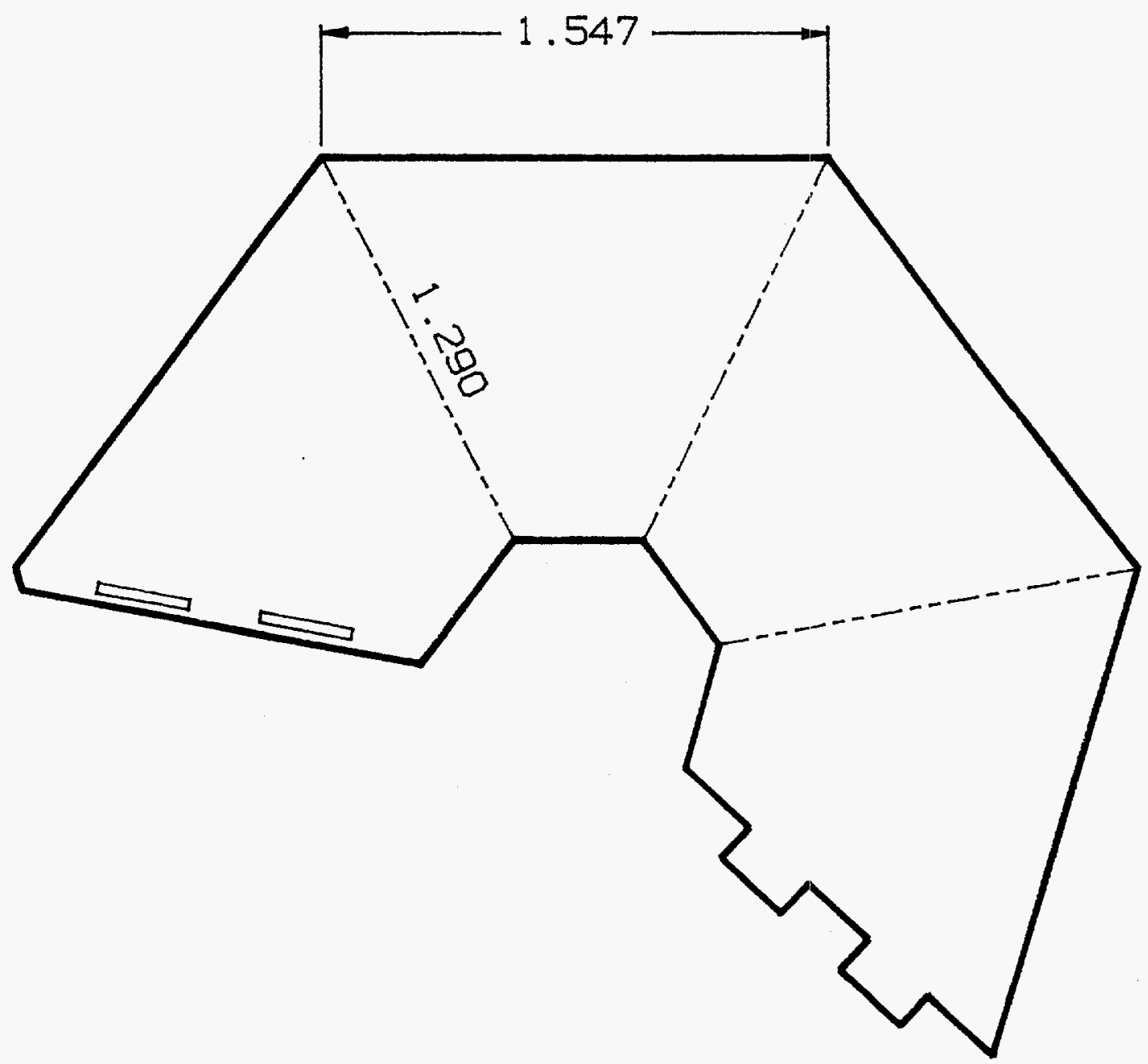

Figure 2.4 Flat Pattern of the Secondary Optical Element. 


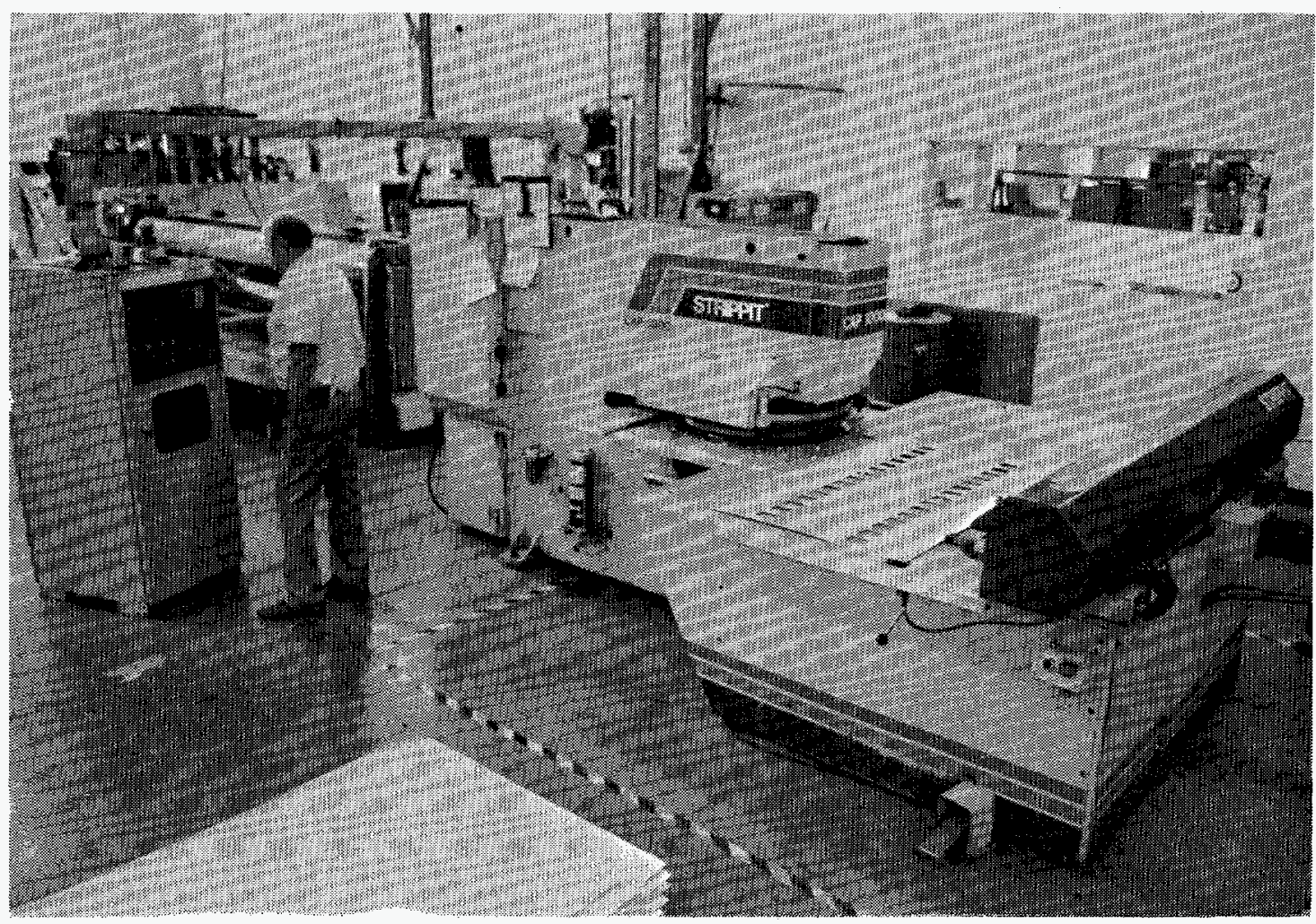

Figure 2.5 Turret Punch Press Used for Fabrication of Heat Spreader, Top Contact, and SOE. 
Secondary Optical Element Mounts: SOE mounts are made from double-sided foam tape using a pressure-sensitive adhesive with peel-off release liner on both sides. The tape is sheared to size with the release liner still on.

Assembly Operation for the Cell Assembly: The current assembly operation started with the heat spreader, pretinned cell, and bottom contact tab. Each was fluxed in the area to be soldered. The heat spreader was set into the assembly fixture, and a pre-cut rectangle of solder set where the cell and bottom contact tab attached. Next, the cell and bottom contact tab were placed in the fixture. Finally, the top contact was set in place. The entire loaded fixture was placed on a temperature-controlled heated platen with internal-resistance heating coils. The temperature was increased until all the solder reflowed, and then the assembly was allowed to cool again. The soldering fixture was fabricated to a tolerance of $+/-0.005$ inch for the PV cell placement on the heat spreader. The accurate positioning of the PV cell is essential to obtain high tolerance alignment with the Fresnel lens positioned above.

After it cooled, the assembly was removed. The release liner on one side of the SOE mounts was removed, and the mounts were adhered to the SOE. The release liner was then removed from the other side, and the SOE was affixed to the cell assembly. The assembly procedure used for the fabrication of the prototype cell assemblies are shown in the process flow diagram of Figure 2.6. The inspection and testing followed. The cell characteristics were noted to allow assembly in matched sets for optimum module performance.

Eabrication Challenges: The PV cell-to-heat spreader solder bond was the most difficult bond to make successfully. This bond has not survived the Sandia environmental cycling specifications. Many variations of the soldering process were used during the development of the cell assembly fabrication technique. Consultation was done with Sandia personnel throughout this development work. The last version used for such a soldering process is described below.

The solder reflow of all the interfaces of the cell assembly was achieved simultaneously with a tooling fixture using a hot plate. The surface preparation steps used for cleaning the heat spreader, top contact, and bottom contact included degreasing and acid etch. The PV cell was cleaned using isopropyl alcohol. Next, the assembly stack was configured in the fixture tooling. First, the heat spreader was placed, followed by application of a mild rosin flux in the area where the PV cell would be positioned. The back of the PV cell was fluxed using a water-soluble acid flux (SF 30). A $0.0005^{\prime \prime}$ foil of precut solder was placed on the back of this PV cell. Then, this cell was placed in the center of the heat spreader, guided by the fixture. Next, the top contact and bottom contact were placed and the fixture was assembled. The tooling fixture with the cell assembly was placed on a hot plate at $525^{\circ} \mathrm{F}$. It took about 2 minutes and 30 seconds for the solder to reflow. At this moment, the cell assembly was removed from the hot plate. It took about 4 minutes for the fixture to cool, and then the fixture was disassembled. 


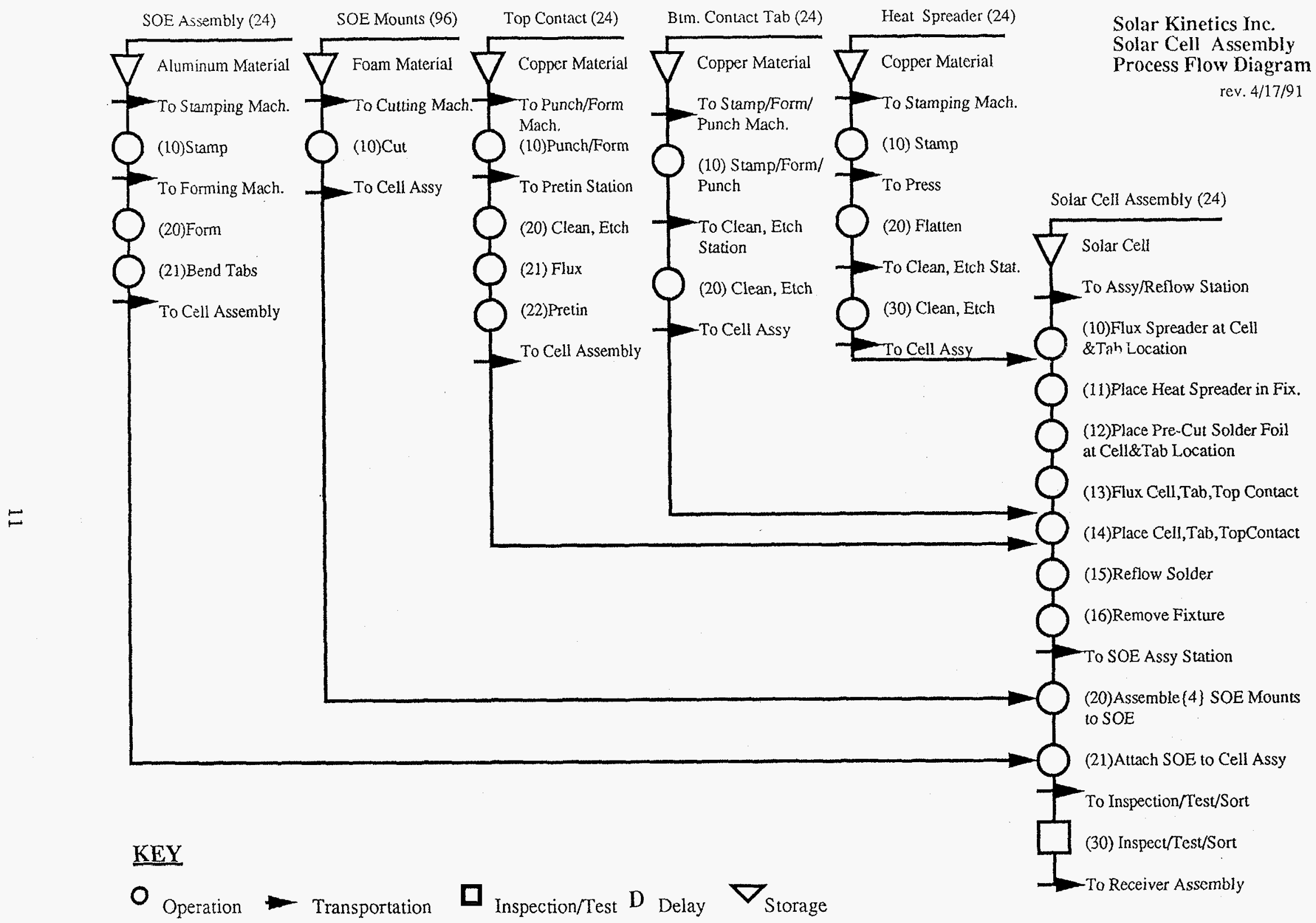

Figure 2.6 Process Flow Diagram for Cell Assembly Fabrication. 
In Sandia's experience, the mildly activated inorganic flux (SF 30) was a good choice. However, because the flux was water based, it generated a great deal of vapor (gas) when heated. This gas could be trapped under the PV cell causing gas entrapment, resulting in voids under the cell. Thus, it was decided to pre-tin the PV cell using the same flux and solder preform, and for the cell assembly fabrication, to flux the pretinned PV cell and the heat spreader using the rosin flux only. This step of pretinning the PV cell before the assembly process enhanced the solder bond. Also, replacing the mildly activated inorganic flux with the rosin flux minimized the void area due to less gas entrapment. 


\subsection{Module Design and Component Fabrication}

Module design activities for this project were directed at three primary areas: (1) appraising current point-focus concentrator module technology, (2) assessing the fabrication possibility of various components in-house, and (3) analyzing key characteristics of the optical, structural, and electrical design. The project team reviewed the SBM III High Concentration PV module design (300X geometric concentration) and the Sandia Baseline Module II design (154X geometric concentration) for attributes with the potential for improved performance and cost reduction $(1,2)$. Solar cell and Fresnel lens component selections were made during the early stages of the project due to the strong impact that these components have on most aspects of module design. Component selection was based on component availability.

This section describes the component selection activities and the optical, structural, and electrical system analyses that defined the improved prototype module design.

\subsection{Component Selection}

A strong design and performance interaction exists between the selection of cell and lens and the other design characteristics of the module. Module specifications such as housing depth, cell package requirements, electrical isolation and interconnection design, thermal characteristics, component alignment tolerances, and others are heavily influenced by the cell and lens design characteristics. In addition, a high level of design coordination is required to ensure that the cell and lens are well matched for optimum performance in the module. This section describes the cell and lens candidates and presents the design selection rationale for these components.

\subsubsection{Cell Candidates}

Selection criteria were established at the outset of this project to guide the cell selection process. These criteria were intended to meet the program goals of designing 15-percent-efficient modules with a reliable design that could be transferred into a production environment. The five criteria for cell selection are listed below.

*High efficiency to achieve 15 percent module efficiency goal

${ }^{*}$ Compatibility with lens designs of injection-molded lens

${ }^{*}$ High reliability

*Low cost in production volumes

*Timely delivery 
Two concentrator cell fabricators were identified as potential candidates for a preliminary screening of concentrator cells. The two bifacial cell suppliers were the University of New South Wales (UNSW) and Applied Solar Energy Corporation (ASEC).

The lens used for the module design was a 6.80-inch-square injection-molded acrylic Fresnel. The point-focus Fresnel-lens was designed by AO using software developed by James Associates. This lens was injection molded, as compared to other lenses that were either compression molded or made by $3 \mathrm{M}$ Corporation using a proprietary Poly Web process to make lens film. The injection-molded lenses may cost much less than compression-molded lenses and still deliver comparable optical efficiencies. They are not expected to have the tolerance problems associated with lens films, and manufacturing will be a single-step process, unlike, that for the lens film. These lenses are expected to be cost competitive with the $3 \mathrm{M}$ lens film Poly Web process.

Environmental safety and health considerations are important factors in developing manufacturing processes, and Methylene chloride is used as a solvent in laminating the lens film onto acrylic sheet. It has been identified as a carcinogen and will be eliminated in production.

The single injection-molded Fresnel lens has an active area of 6.80 inch square and a 0.375 -inch mounting rib on two consecutive sides. The lenses have optical efficiency greater than $80 \%$ and have curved, variable-width large facets numbering less than 23 . These facets are of a fixed height of 0.125 inch. This lens is designed to provide a nominal $300 \mathrm{X}$ concentration on the PV solar cell at a lens-to-cell spacing of 10.1 inches.

The housing depth is principally determined by the lens design and the cell size. A preliminary analysis of housing depth was conducted using the lens design developed by American Optical Corporation (AO). The injection molded lens developed by $A O$ was the only practical choice of lens because of its promise of availability and low cost. Performance estimates with this lens design confirmed its compatibility with the cell design as evidenced by full, reasonably-uniform illumination of the cell active area. This analysis indicated that the preferred housing depth was 10.1 inches for the ASEC cell.

In the final analysis, non-technical factors played the most important role in the cell selection process. The ASEC cell design was selected because the assurance of timely delivery was an overriding concern.

\subsubsection{Lens-to-Cell Spacing Analysis}

As described in the previous section, the analysis indicates that a 10.1-inch lens-to-cell spacing produces the maximum module output. These results were obtained from performance comparisons of ASEC cells without prismatic covers under nonuniform illumination. Slight deviations from the design lens-to-cell spacing were estimated to 
have minimum impact on module performance. The lens-to-cell spacing was determined by Sandia using the James and Associates PV Fresnel lens design Software.

\subsubsection{Secondary Optical Element Design}

The secondary optical element (SOE) concept selected for the prototype module was a four-sided reflective component. Other design concepts, such as total internal reflective glass SOEs and imaging glass SOEs were considered, but were regarded as too costly to develop for this project. Figure 2.4 displays the flat pattern of the SOE. The procedures for development of the specification are discussed below.

Three SOE design parameters were evaluated with the software by Sandia: slope, height, and exit aperture. The slope is the angle between the cell normal and the inner surface of the SOE. The SOE height is measured from the cell plane perpendicular to the SOE entrance aperture. The exit aperture is measured across the bottom plane of the SOE. Several considerations influence these design characteristics. The most important consideration pertains to the geometrical relationship between the lens, SOE, and cell. Additional considerations include the incidence angles of rays striking the SOE surface and reflecting to the cell surface, because these angles influence the reflective efficiency of the SOE and the optical efficiency of the anti-reflective coating on the cell. Finally, other considerations of SOE design are the allowances for manufacturing and placement tolerances of the SOE.

The SOE angle selection was based on the software-predicted performance estimates. The 30-degree angle was selected to give better performance at a maximum pointing error of 1 degree.

The design criterion for determining the SOE height and angle was to collect and reflect all rays toward the cell for the extreme sun-pointing errors. The 1.0-inch high, 30-degree angle SOE design met this condition.

The SOE is mounted onto the top contact using a double-sided adhesive-foam tape. The foam is 0.040 -inch thick and provides the resilience during thermal cycling. The foam material can survive up to $200^{\circ} \mathrm{F}$ for short periods. During thermal cycling, the cell assemblies (and the foam) are never exposed to temperatures higher than $200^{\circ} \mathrm{F}$.

\subsection{Module Structural Analysis}

The module structural design objective was to verify the applicability of the baseline structural design for the $300 \mathrm{X}$ module. Analyses were performed in three principal areas: housing strength, housing buckling, and parquet deflection. A design was developed for the parquet-to-housing clip. These activities are described in the following sections. 


\subsubsection{Housing Strength Analysis}

Housing strength was evaluated for the configurations of a 24-cell module. The module configuration was 2 cells wide by 12 cells long. The housing material was selected to be $(0.040 \mathrm{inch}) 5005$ aluminum. The module analysis included the lens parquet support by sheet metal bulkheads. The strength and deflections were calculated for the structural portion of the module. This portion included the housing, the internal support (sheet metal), and the acrylic lens parquet.

Detailed structural analysis was performed for the module housing. The analysis considered survival loads of $23 \mathrm{psf}$ ( $90 \mathrm{mph}$ winds), and strength and operating loads of $2 \mathrm{psf}$ ( $27 \mathrm{mph}$ winds). For survival loads, buckling analysis of the sheet aluminum was considered as a primary failure mode candidate. In most of these analyses, the bottom was considered as a flat sheet, that is without corrugations. Final analysis also considered a corrugated bottom that was later selected as the baseline design. This corrugation helped to stiffen the bottom of the housing. In addition to the wind loads, a gravity load of 10.5 psf for the 2-by-12 module was also considered. The maximum operating deflection of the pan, with bottom corrugation, due to gravity loads, was less than 0.003 inch and the maximum rotation was less than 0.05 mradian.

The module was also analyzed for torsion. The applied load for the torsion was $150 \mathrm{inch}-\mathrm{lbf}$ for deflection and $537 \mathrm{inch}-1 \mathrm{bf}$ for stress. The resulting maximum rotation is 0.01 milliradian, and the maximum stress is 55 psi. Thus, the torsional analysis of the module resulted in insignificant torque on the module. So the module is stiff to torsion.

The structural analysis also suggested that there is no significant advantage in supporting the housing at intermediate points. The recommendation is to support the module at the end caps. The resulting housing stresses and deflections are low.

Under the operating wind load conditions of $27 \mathrm{mph}$, the deflection of the module at the center of the aluminum pan was less than 0.03 inches. The maximum rotation of the cell assembly was less than 6 milliradians.

\subsubsection{Lens Parquet Deflection Analysis}

A scoping analysis was conducted to establish the bounds of lens parquet surface dislocation due to wind loads. Module performance may be impaired due to lens cupping between parquet support points. Sandia has measured significantly different flux patterns for fabricated lenses due to cupping or bowing of the lens.

The support of the parquet edge at the housing rim is in reality an elastic support. The edge condition considered was simply supported (free to rotate at the edge). This case corresponds to an upper bound on deflection (worst case). The simplified plate theory was used in the calculations. 
These calculations gave the maximum normal stress in the Fresnel Lens to be 300 psi. This was much lower than the yield strength ( $6000 \mathrm{psi}$ ) of acrylic. Therefore, stress from bending is not an issue.

Various mounting arrangements were evaluated for the supporting of the lens parquet on the module aluminum housing. Intermediate supports were evaluated, and they had limited effect on center deflection unless the aspect ratio was small. Support or bulkheads, every two lenses, reduced the sag to 0.030 inch from 0.080 inch for no intermediate supports.

\subsubsection{Lens Parquet Gasketing Material Selection and Tests}

Solar Kinetics conducted tests on gasket material products considered as lens parquetto-housing sealant candidates. The objective of this testing activity was to determine the compressive characteristics of the candidate gasket materials. Compressive yields strengths were measured for loadings up to $100 \mathrm{psi}$. The sealant tape should also provide for movement due to thermal and humidity expansion between the aluminum housing and the acrylic lens. Various adhesive tapes were tested. The material selected was a 0.003 inch thick Teflon tape with silicone adhesive on one side.

\subsubsection{Thermal Adhesive Selection and Tests}

We conducted a series of tests to select a thermal adhesive for bonding the cell assembly heat spreader to the housing bottom. Selection criteria included compatibility to aluminum and copper, high thermal conductivity, thin bonding properties, no post-cure outgassing, appropriate cure and service temperature, and low solar absorptivity. Epoxides, acrylics, and silicones were considered. In order to test the adhesives under conditions similar to actual service, the adhesive bonds between the copper heat spreader and the aluminized steel were subjected to a 30-watt thermal load.

Several silicone adhesives were tested under thermal loading and tensile loading conditions. Most of the silicones exhibited satisfactory temperature and bonding strength characteristics. Two candidates were selected for further examination: DOW 3140 (one part silicone with 50 percent aluminum oxide) and Shin Etsu X-31-751 (one part thermally conductive adhesive).

The Shin Etsu product was analyzed by Sandia to confirm the fill material and percent composition. These analyses indicated a 60 percent by weight fill of aluminum oxide. A desirable characteristic of this adhesive was the fine, uniform size of the fill particles. Particle sizes ranged from 2-5 microns (0.08-0.20 mils). The Shin Etsu X-31-751 thermal adhesive was selected for use in the module because the small uniform aluminum oxide particles should lead to easily controlled, minimal bond thicknesses. 


\subsection{Fabrication of the Module}

\subsubsection{Pan End Caps}

The prototype module end caps were designed and machined. The design is such that these end caps could be stamped at low cost, with minimal design changes. A fabrication drawing of the end cap is shown in Figure 3.1. The parts are relatively simple to fabricate and require tolerances well within standard commercial practices.

After the end caps had been received, the areas where the module mounting brackets were to be spot welded were prepared by solvent wipe and mild abrasive cleaning. They were spot welded to the exterior surface of the end cap in a manual single-station resistance spot welder.

The same electrical insulating polymer film used on the main pan assembly was next individually laminated to the inside surface of each end cap.

\subsubsection{Pan Assembly}

The housing was designed to provide for high-tolerance placement of the PV cell assemblies, all associated electrical interconnection, and Fresnel lens parquets. The fabrication drawing of the housing is shown in Figure 3.2. The pan assembly, also referred to as the module housing, was made from aluminum coil stock. It was first laminated on what would be the housing inner surface with an insulating polymer film to provide electrical isolation from the electrical circuits inside the module. Lamination is a continuous coil processing operation involving uncoiling, leveling, dry laminating and sheeting or cut-off as shown in Figure 3.3. The sheets were taken to a $\mathrm{CNC}$ semi-automatic press brake. Here, an operator oriented the sheet in the press and the press sequentially bent the part according to preprogrammed backstop positions and ram closing heights. The stop and closing height settings determined the location and degree of each bend. Special soft dies and pressure-distributing bladders were used to ensure uniform and repeatable bends. The automated backstops provided excellent accuracy of bend location to maintain correct lens-to-cell spacing.

In preparation for end cap installation, the film was peeled away from the ends of the housings where the end cap would be fitted. The areas to be welded were prepared with a solvent wipe and light abrasive cleaning.

The housings were set in a fixture to maintain the cross-sectional shape as required. The end caps were fixed in place with their lips flush with the outer edge of the housing edge. A temporary cooling medium was placed on the inside corner where the housing and end cap meet to serve as a heat sink during the next welding step. The edges of the housing and end cap were continuously fused without use of additional filler metal using a Gas Tungsten Arc Welding (GTAW) weld process. The cooling medium was removed, and the laminate edge smoothed down against the cooled metal. Additional 

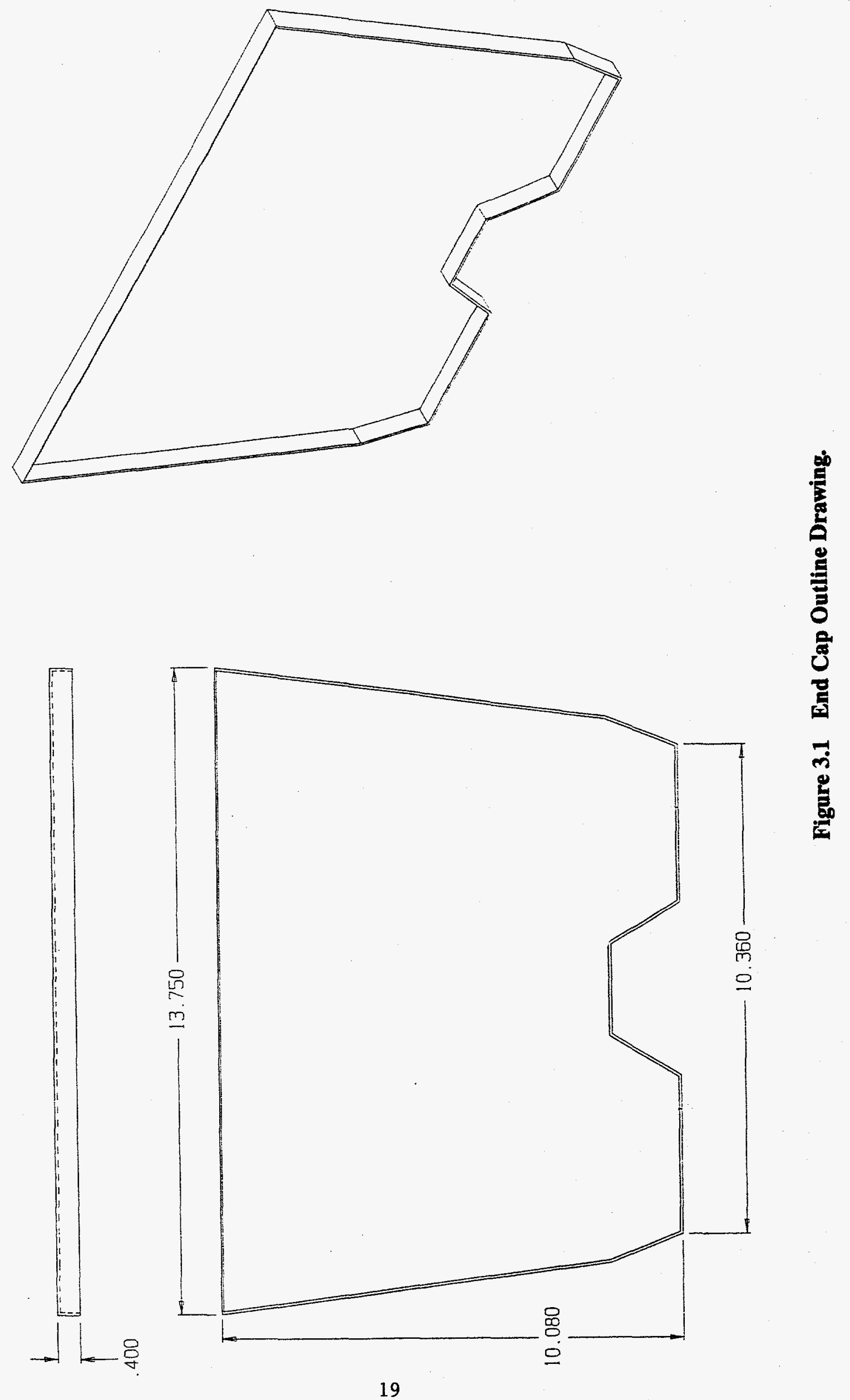


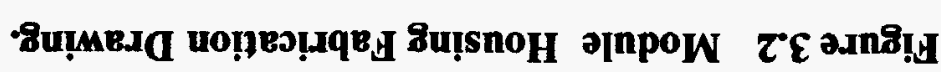
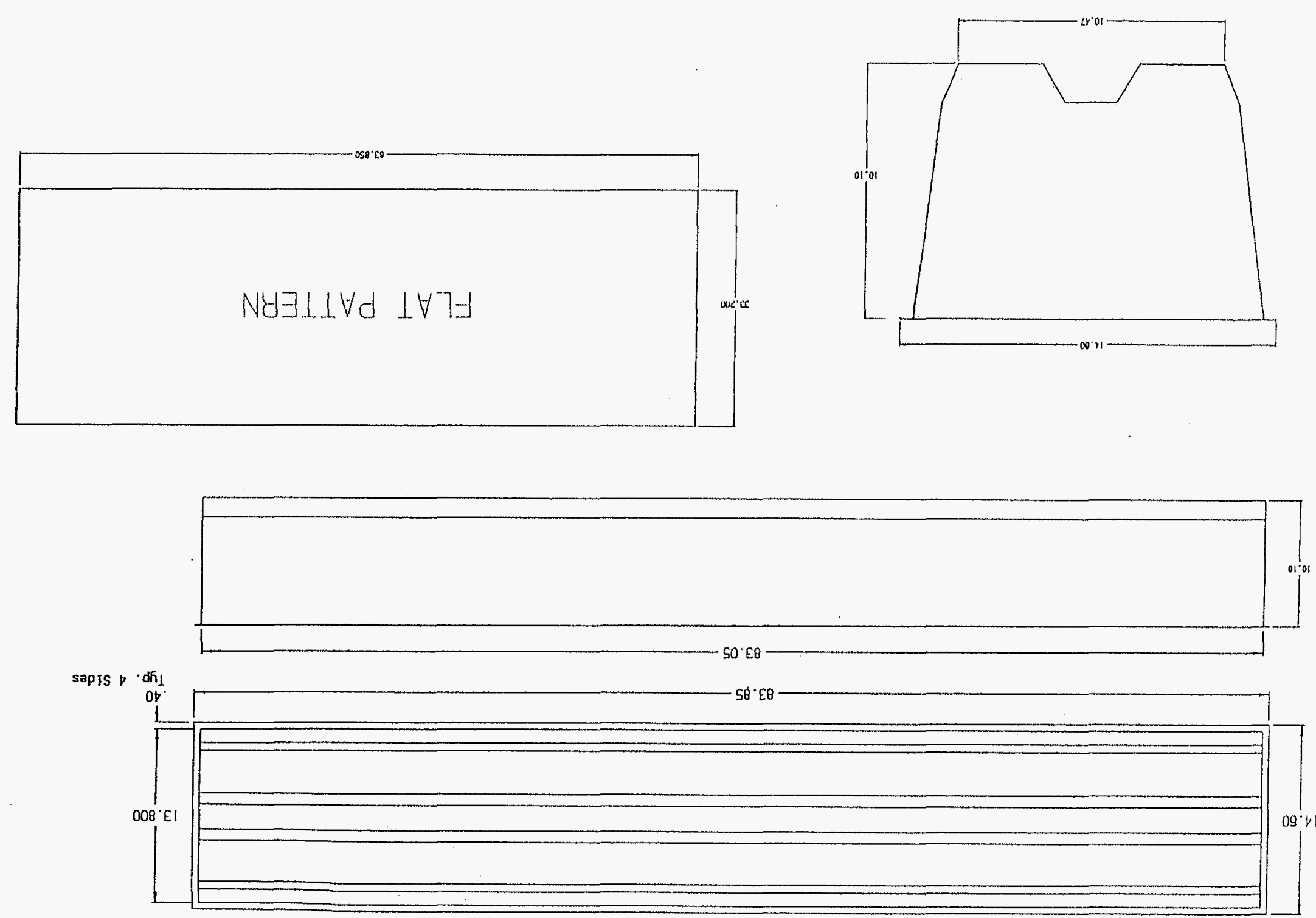


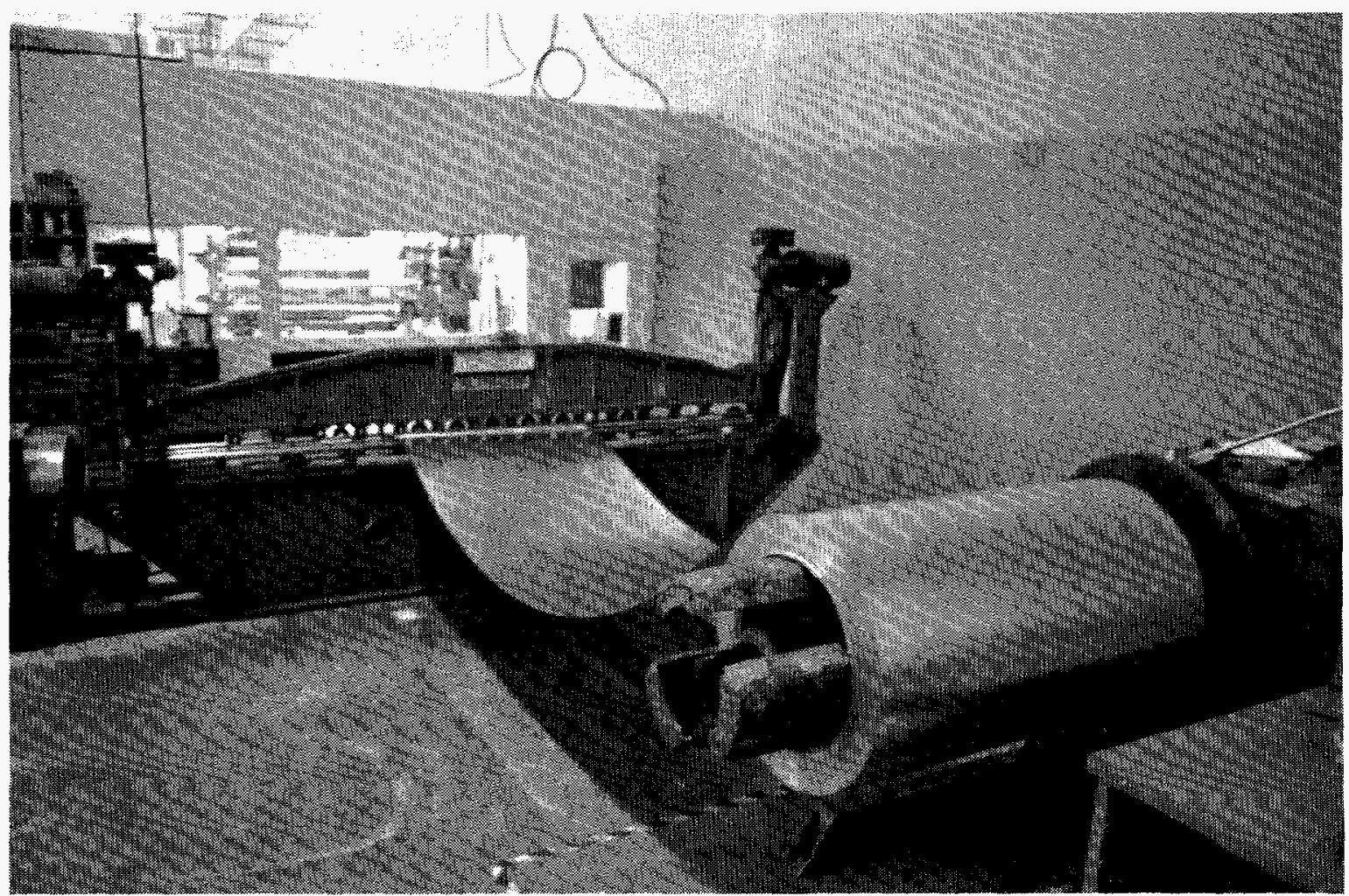

Figure 3.3 Module Housing Lamination Process. 
silicone RTV sealant was applied to ensure complete isolation of the metal housing from any electrical component in the module.

The completed part was dimensionally checked by a coordinate measuring machine for adherence to tolerances.

\subsubsection{Electrical Interconnects}

The electrical interconnects were made from flat copper coil stock. The coil stock was 0.016-inch-thick, 1-inch-wide OFHC copper. There were six different types of interconnects. Some required a hole to be punched in one end to mate with the bypass diodes. Some had right-angle folds, and several had expansion stress-relieving loops in them as shown in Figure 3.4. These operations were performed on single-station presses. The punching tooling was standard. The loop-bending tooling was custom made for this operation.

Where the ends of the interconnects were to be soldered, the specific areas were degreased, etched, rinsed, and pretinned.

\subsubsection{Planned Procedure for Receiver Assembly}

The first step in receiver assembly would be to align the housing pan in the assembly fixture. This alignment is important to assure that the PV cells are positioned where the lens focuses the sunlight. Adhesive would be dispensed onto the pan where the cell assemblies would go. A placement fixture will position the cell assemblies correctly and apply pressure to the assemblies during the adhesive cure.

The same Shin Etsu adhesive will be used to fasten the ceramic pads to the housing pan at the locations the electrical interconnect's expansion loops would be located. These pads will ensure long-term electrical isolation of the interconnect from the housing pan.

The pan would be removed from the fixture and moved to the interconnect installation station. The diode mounts will be installed using the same adhesive used for the cell assemblies and insulation pads. Interconnects will be installed according to the appropriate circuit pattern. The interconnects would all be soldered at both ends to ensure long-term connection integrity. Since all mating parts for soldering will be pretinned, the joints only require brief reflow at each joint.

An electrical test of each receiver will be done at this time to ensure correct diode and interconnect installation. An insulation standoff test will also be conducted on each module.

The receiver assembly process includes placing the cell assemblies and diode assemblies in the module pan and then attaching the electrical interconnects. 


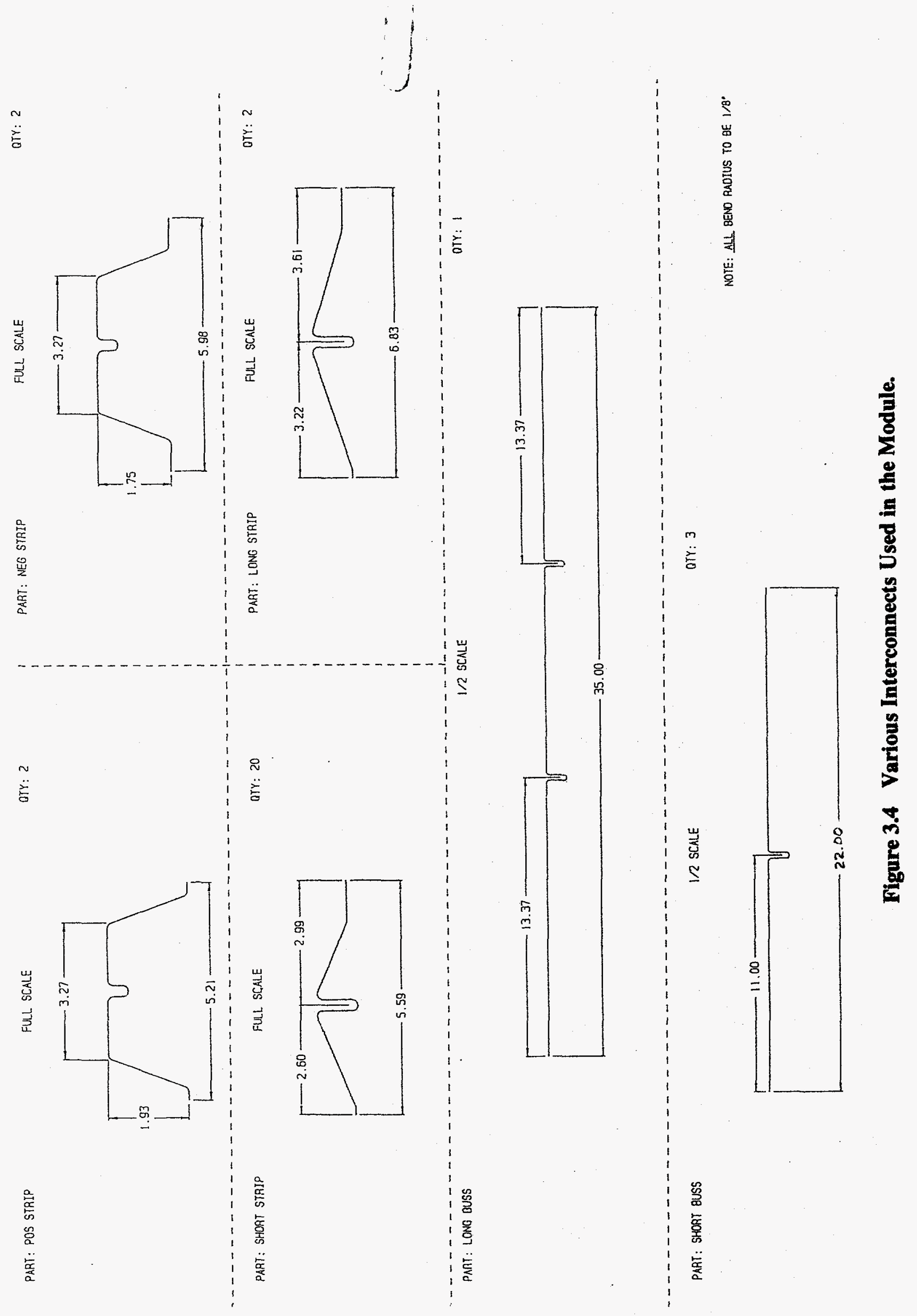




\subsubsection{Module Assembly}

The module assembly will include the receiver assembly, just described, plus the lens parquet and lens-mounting hardware. This hardware will include edge-clip and lenspartition extrusions plus tape and sealant. This assembly is the last step of module fabrication.

\subsubsection{Lens-Partition Clips}

For prototype fabrication, the aluminum lens-partition clip is a machined component easily adaptable to low-cost extrusion. When installed, it performs two primary functions. It supports and seals the two adjacent edges of neighboring lens parquets. It also reinforces the module housing against cross-sectional distortion because it is fastened as a span across the open side of the module housing.

In our module, the lens partition clip cross section with a receiving slot on two sides allowed the first function to be accomplished. The second function could only be accomplished when each end of the partition clip was securely fastened to the housing edge. Each end of the clip was drilled and then machined to have a contour that closely matched the housing contour.

\subsubsection{Lens Parquet Assembly}

Lenses are currently received as single units as shown in Figure 3.5. Each lens is one-fourth of a $2 \times 2$ parquet design which is being developed by American Optical $(\mathrm{AO})$. The edges of four lenses were trimmed on two adjacent sides to remove the flat outer perimeter. The trimmed edges were then solvent-bonded to one another to form a $2 \times 6$ parquet of twelve lenses as shown in Figure 3.6.

SKI purchased 300 single lenses from AO because parquets were not available. The plan was to solvent-bond these lenses to form a $2 \times 6$ parquet, as shown in Figure 3.6, for use in the prototype module. The single-piece lenses as received had various defects. These included a few small melt/run marks on the curved surface of the facets, and the flat back surface of the lens was convex due to facet shrinkage stresses. These defects did not significantly reduce the optical performance of the Fresnel lens, but did change the optimum lens-to-cell spacing from 10.0 to 10.1 inches.

To fabricate the $2 \times 6$ lens parquet, we first thermally stress relieved each lens in an oven at $175^{\circ} \mathrm{F}$ by placing the non-faceted (flat) side onto a glass plate for 3 hours. This made the Fresnel lens flat to within $+/-0.020$ inch and was acceptable for the purpose of assembling the parquet. There was a $20 \%$ rejection of these reworked lenses. This step will not be necessary when $2 \times 2$ parquets are available. Next, some of the lenses were milled along one of the two edges with the 0.375 -inch flange. This flange was machined off so that these lenses could be used as the inside lenses of the solventbonded parquet. The solvent bonding was achieved using the acrylic solvent Methylene chloride. Once the 12 lenses required to make a single $2 \times 6$ lens parquet were 


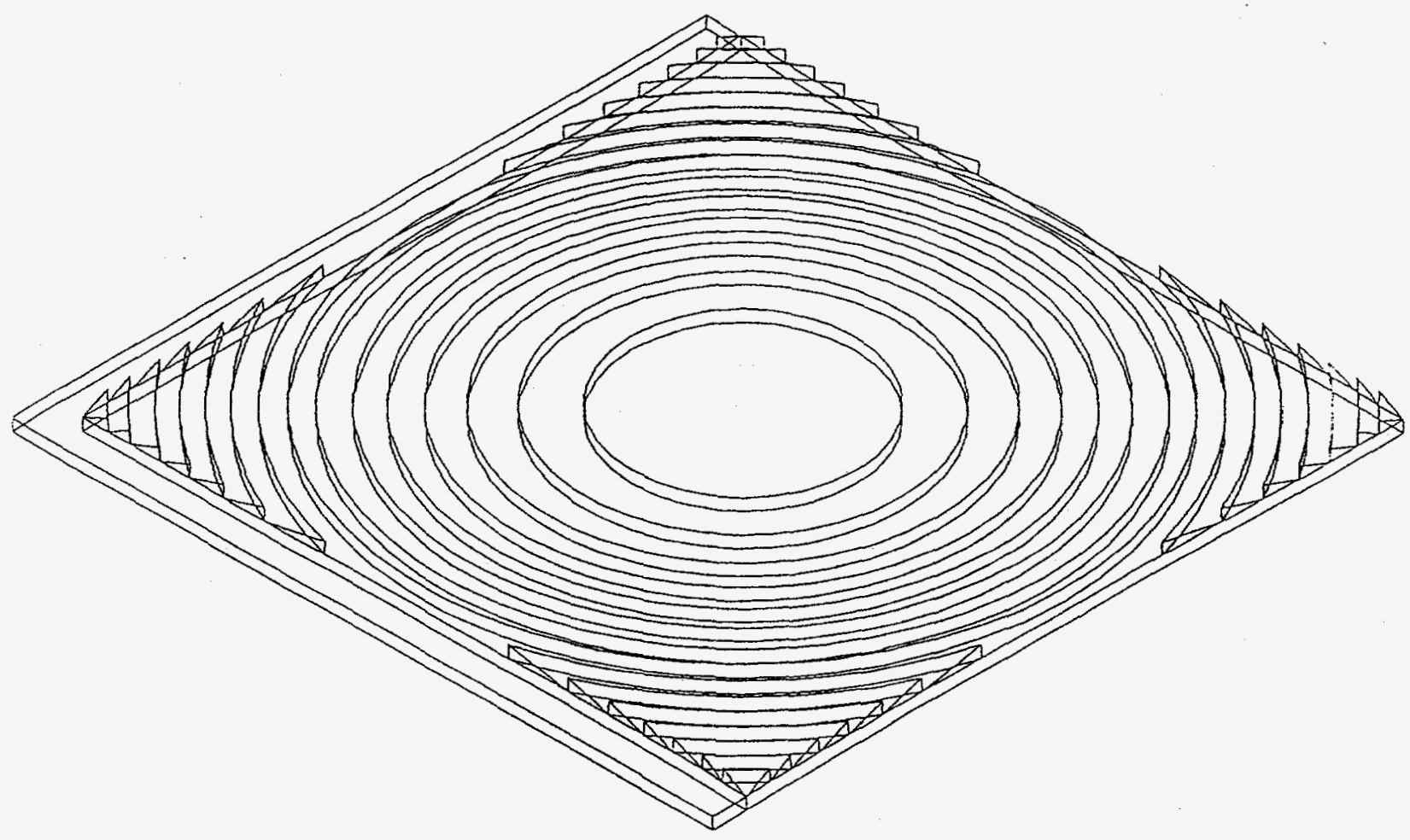

Figure 3.5 Single Injection-Molded Fresnel Lens. 


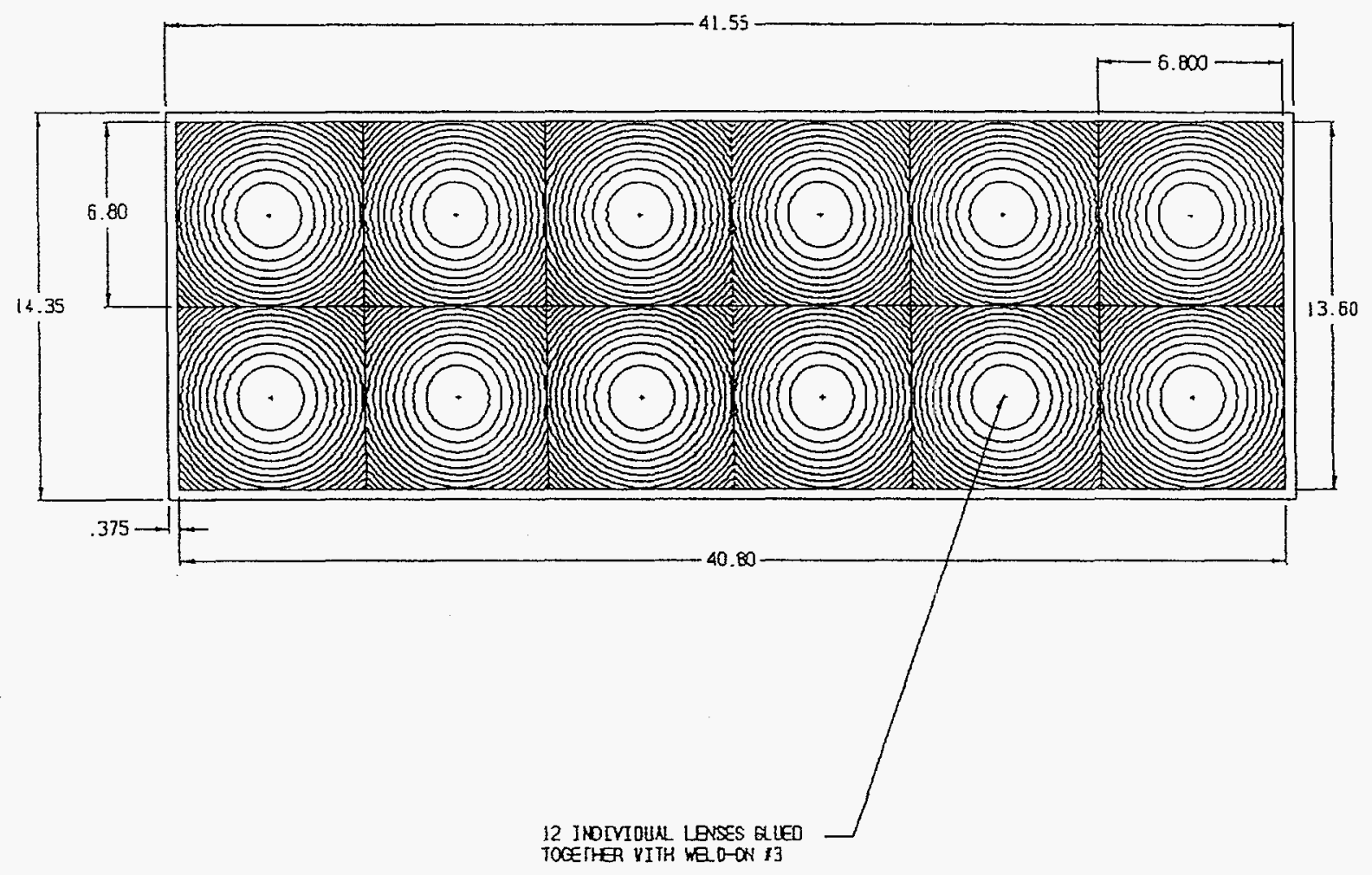

Figure 3.6 Solvent-Bonded 2x6 Fresnel Lens Parquet. 
machined, they were assembled into a parquet fixture on a T-slot surface table. Next, methylene chloride was injected along the seams with a medical syringe. This procedure was done first on the faceted side and then on the opposite side. The overall dimension of the parquet was within $+/-0.030 \mathrm{inch}$.

The $2 \times 6$ parquet has a flat, unfaceted perimeter edge. Teflon tape with pressure-sensitive adhesive was applied to the rear side of this edge. Partition edge clips were used to attach two parquets together to form a $2 \times 12$ lens assembly.

\subsubsection{Edge Clips}

The edge clips were made from a custom aluminum extrusion. The extrusion is received in 12-foot or longer lengths. The drawing of the extruded clip cross section is shown in Figure 3.7. The first operation was to cut the side and end clips to length. This was done on a band saw. The ends were then miter cut to join smoothly at the module corners. The cut edges were manually deburred before transfer to the next operation.

\subsubsection{Mock Module Assembly}

The objective of this task was to evaluate the module housing-to-lens interface for tolerance to humidity/freeze cycles. A second objective was to subject the module to the standard rain test after the humidity/freeze cycling and observe the module for water leaks. A mock module was fabricated and delivered for these purposes. The mock module consisted of the aluminum housing with bulkheads, and two approximately 0.125 -inch thick plano-plano Lucite acrylic sheets. These two acrylic sheets were a substitute for the $2 \times 6$ Fresnel lens parquets. A lens partition clip and edge clip as described above were used to mount the simulated lens onto the aluminum housing. No sealant was used inside the edge clips. The mitered-corners of the edge clips were sealed with clear silicon. Figure 3.8 shows the placement of the edge clip and the RTV sealant. This module also had a drain plug and a moisture vent on opposite end caps of the aluminum housing. The lens partition clips were fastened in place with self-drilling and self-tapping screws. Next, the edge clips were installed around the entire lens perimeter. No fasteners were needed to retain the edge clips. Silicone RTV sealant was applied in the corners and where the edge and perimeter clips meet. 


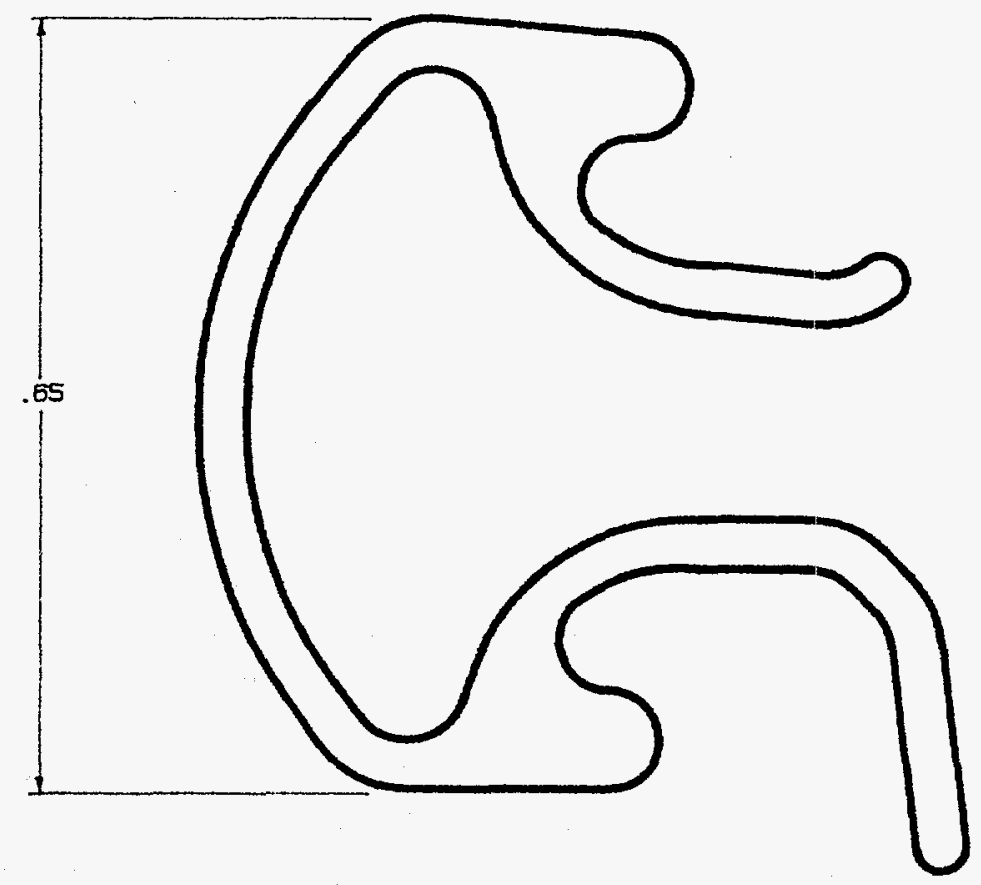

Figure 3.7 Cross Section of the Extruded Edge Clip. 
COMPLIANT SILICONE EDGE SEALER

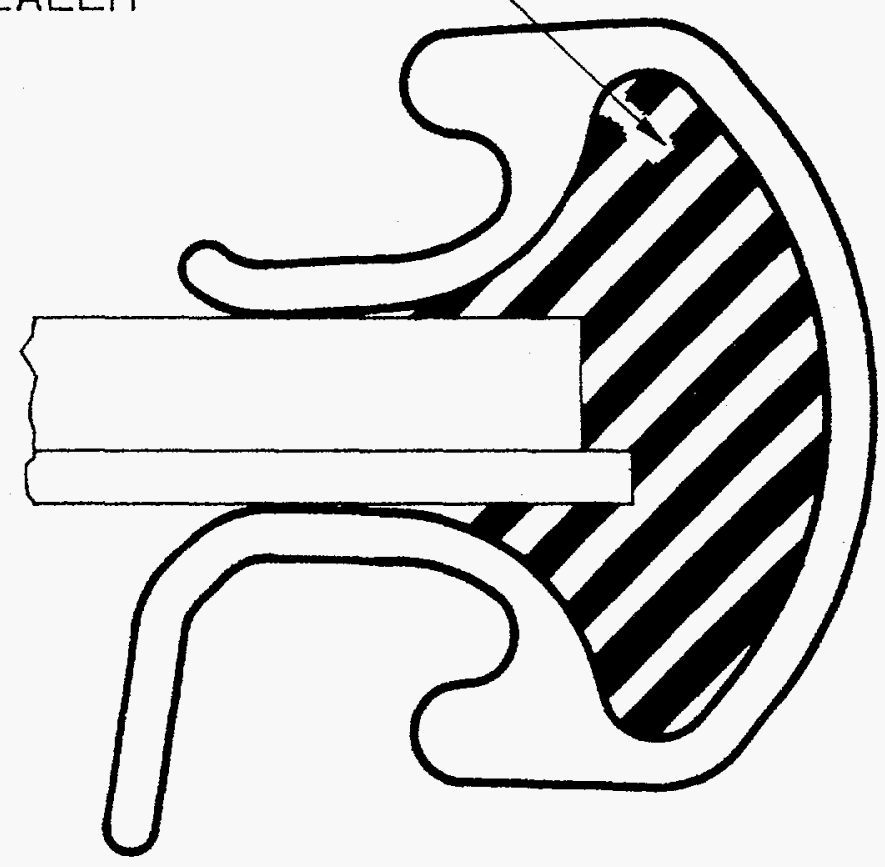

Figure 3.8 Placement of Edge Clip and Edge Sealer. 


\subsection{Cell Assembly Evaluation}

Two sets of cell assemblies were fabricated by SKI and submitted to Sandia for evaluation tests. The various tests that the cell assemblies were subjected to are described in the "Qualification Tests for Photovoltaic Concentrator Cell Assemblies and Modules" (3). Under this Pre-concentrator Initiative contract, SKI worked on the cell assembly fabrication development. Substantial effort was involved in developing soldering techniques for the direct bonding of a PV cell to a copper heat spreader. This section describes the hardware submitted and the test results.

Under the contract, SKI submitted complete and incomplete cell assemblies for various evaluation tests. These test specifications included:

*Initial inspection (visual),

*High voltage stand-off test (Hi-pot),

*Initial $\mathrm{x}$-ray and ultrasonic evaluation,

*Baseline electrical performance characterization,

*Thermal cycling,

*Humidity/Freeze test,

*Final $x$-ray and ultrasonic evaluation, and

*Final high voltage stand-off test.

Multiple sets of evaluation samples were submitted as required for testing and evaluation purposes.

The SKI cell assembly is shown in Figure 2.1. In a complete module, twenty-four of these assemblies will be adhesive bonded to the bottom of the concentrator module aluminum housing (pan). The inside bottom of this pan will be lined with 0.002 -inch thick film of (CT-412L), DuPont Tefzel with acrylic adhesive and a release liner. The cell assemblies will be bonded to the Tefzel film with approximately 0.005 -inch thick layer of Shin Etsu X-31-751 thermally conductive dielectric moisture cure RTV. This adhesive and the film provide the electrical isolation between the cell assemblies and the pan while providing high thermal conductivity.

To evaluate the various bonds and layers of the cell assemblies, partial cell assemblies were fabricated for submittal to Sandia. Figure 4.1 shows a flow diagram for the sequence of the evaluation tests. Such partial or layered fabrication helps in detailed diagnostics of appropriate interfaces by bond evaluation techniques like radiography and ultrasonics. 


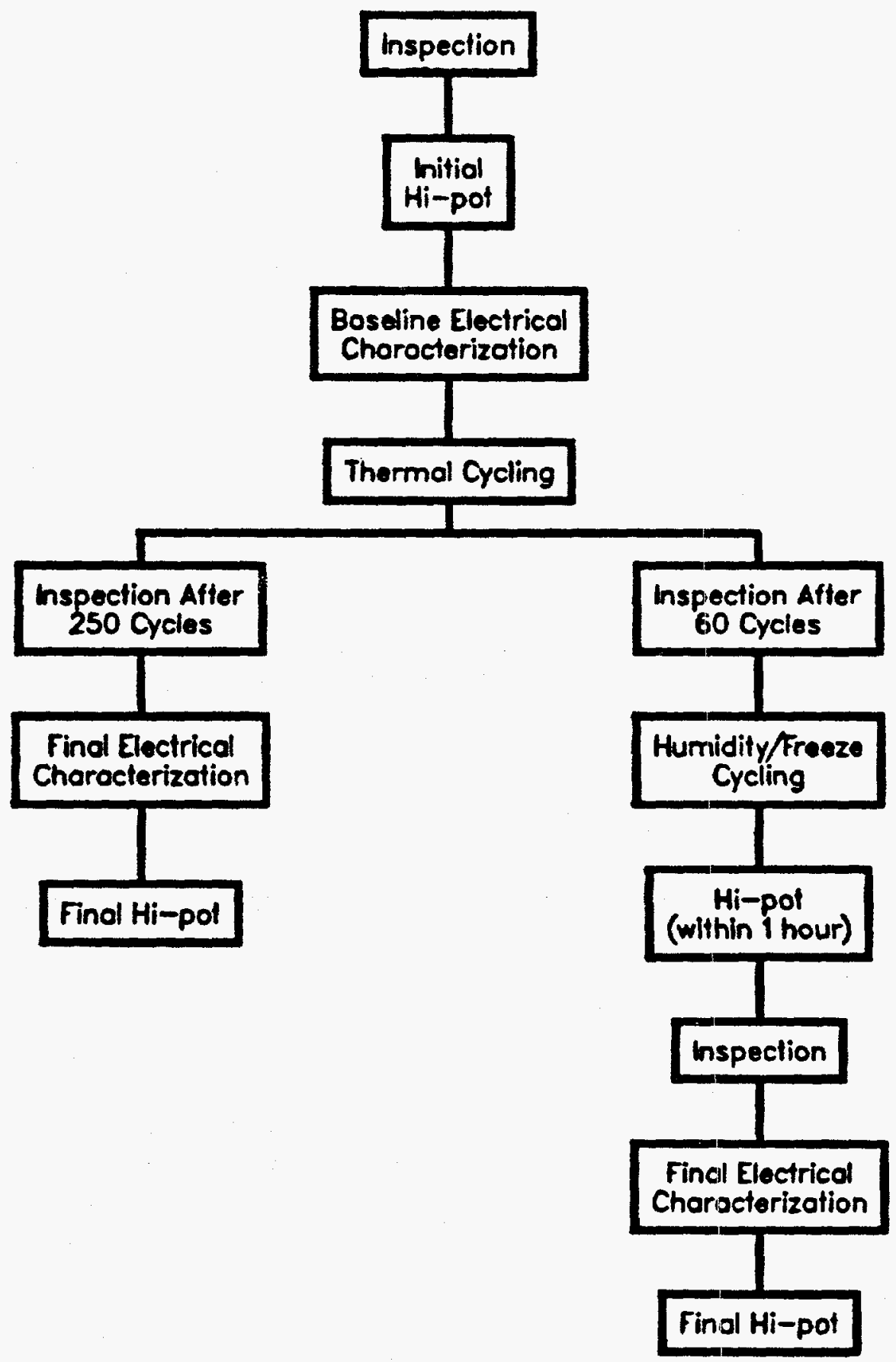

Figure 4.1 Test Sequence for Cell Assemblies. 


\subsection{First Set of Cell Assemblies}

\subsubsection{Configurations for Evaluation Tests}

To accurately evaluate the cell assemblies, three different configurations were fabricated and delivered. To evaluate the electrical stand-off (isolation) property of the adhesive, cell assemblies were bonded with the Shin Etsu adhesive to a 3-inch-square section of the aluminum laminated with the dielectric film, Tefzel. Five cell assemblies (CA-80 thru 84) were delivered to Sandia. Figure 4.2 shows the configuration of these cell assemblies as they were bonded to the Tefzel-laminated aluminum section (4).

When these assemblies were delivered, SKI was planning to fabricate the cell assembly interconnects as one piece to be soldered to the heat spreader after they were bonded to the module pan. Thus, the bottom contact, as shown in Figure 2.1, would be eliminated, and the interconnect would be directly soldered to the heat spreader. Therefore, the bottom contact was not included in configuration 1 of the cell assemblies. Later, it was determined that the interconnects could not be soldered to the heat spreader after the cell assemblies were installed in the module. This was because the dielectric film adhesive could not tolerate the temperature required for soldering. Thus, the bottom contact was again added to the cell assemblies. To evaluate this heat-spreader to bottom-contact solder bond, a second configuration (configuration 2) consisting of only these two parts soldered together was delivered. The configuration 2, partial cell assembly is shown in Figure 4.3. Three such partial cell assemblies (CA-2, $2 \mathrm{~A}$, and 4) were delivered to Sandia for evaluation.

Sandia had some concern that the large stack up of materials in configuration 1 (complete cell assembly) would be too thick and contain different resilient materials. This could make interpretation of the ultrasound pictures of the cell-to-heat spreader bond difficult. Therefore, SKI furnished a third configuration (configuration 3). This configuration consisted of the heat spreader, the cell, and the top contact all appropriately soldered as shown in Figure 4.4. These partial cell assemblies were identical to configuration 1, except for the absence of the module pan and the secondary optical element (SOE). Three partial cell assemblies (CA-75 thru 77) of this configuration were delivered.

Because of the different configurations, the complete evaluation test sequence was not planned for all of them. Configuration 1 samples were planned for the full test sequence. The configuration 2 samples were planned for thermal cycling tests and the pre-and post-ultrasounds. Configuration 3 samples did not have the electrical isolation components, thus, they were subjected to all qualification tests except for the hi-pot tests. 

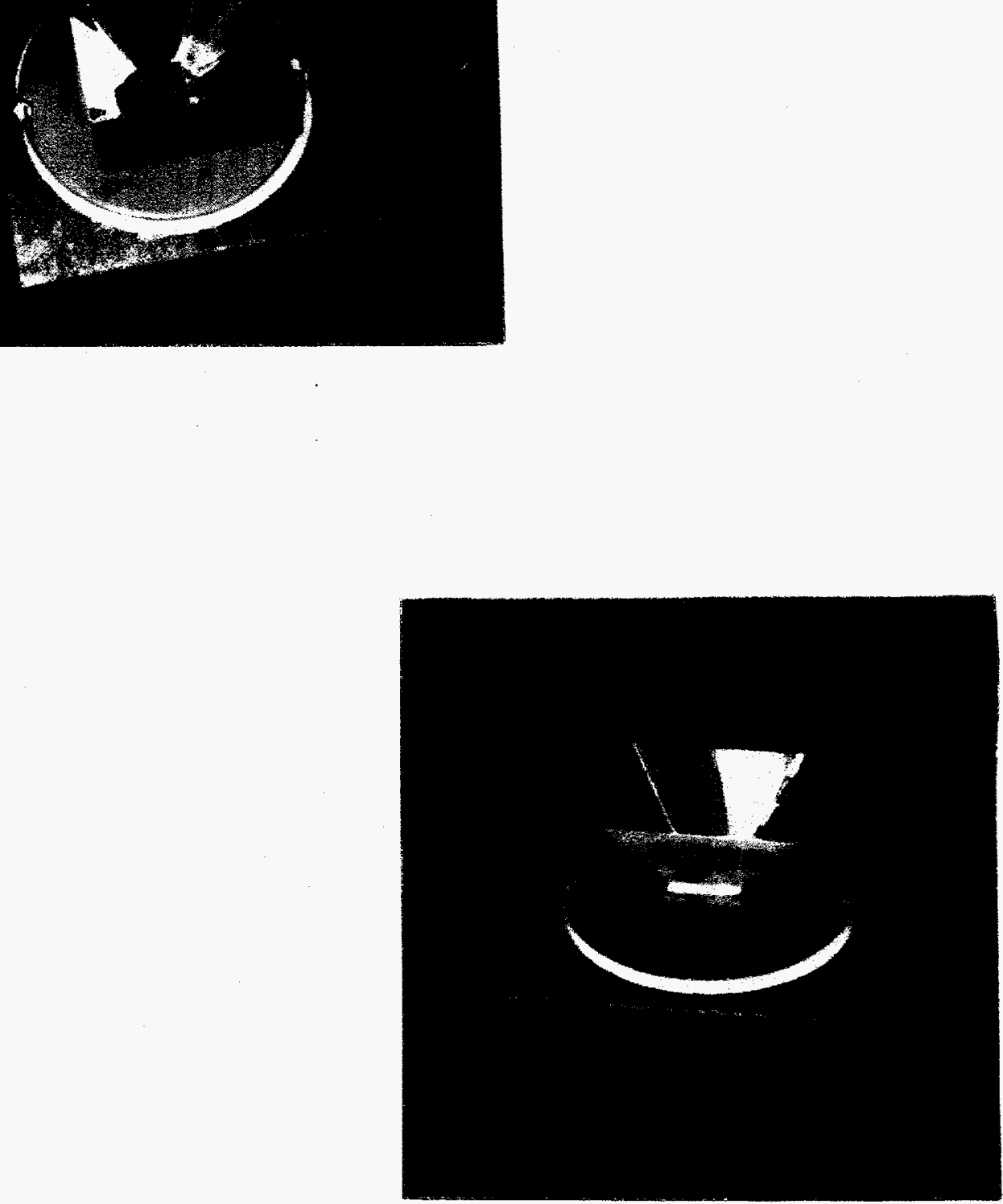

Figure 4.2 Cell Assembly - Configuration 1. 


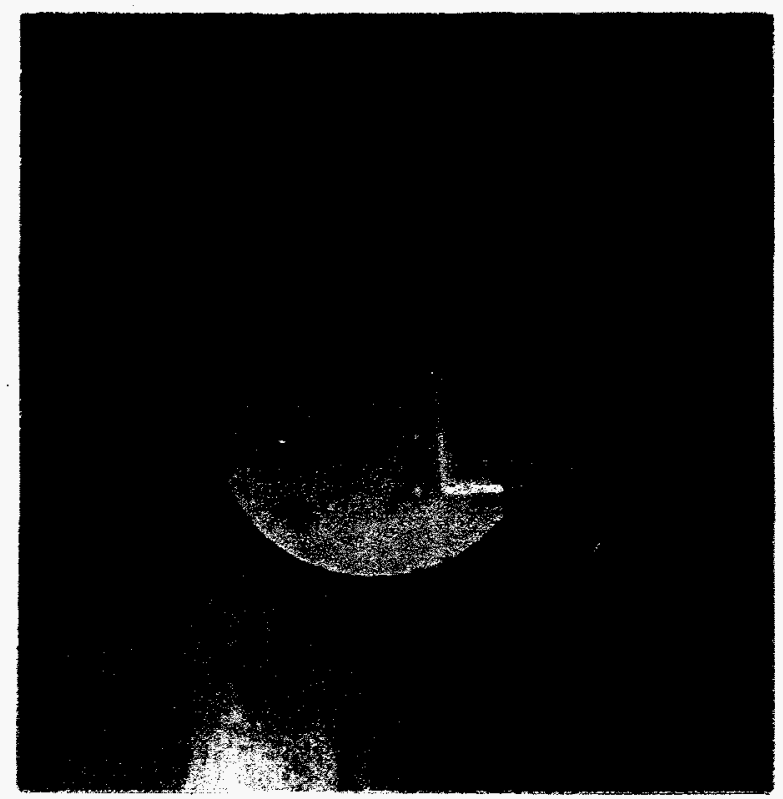

Figure 4.3 Partial Cell Assembly - Configuration 2.

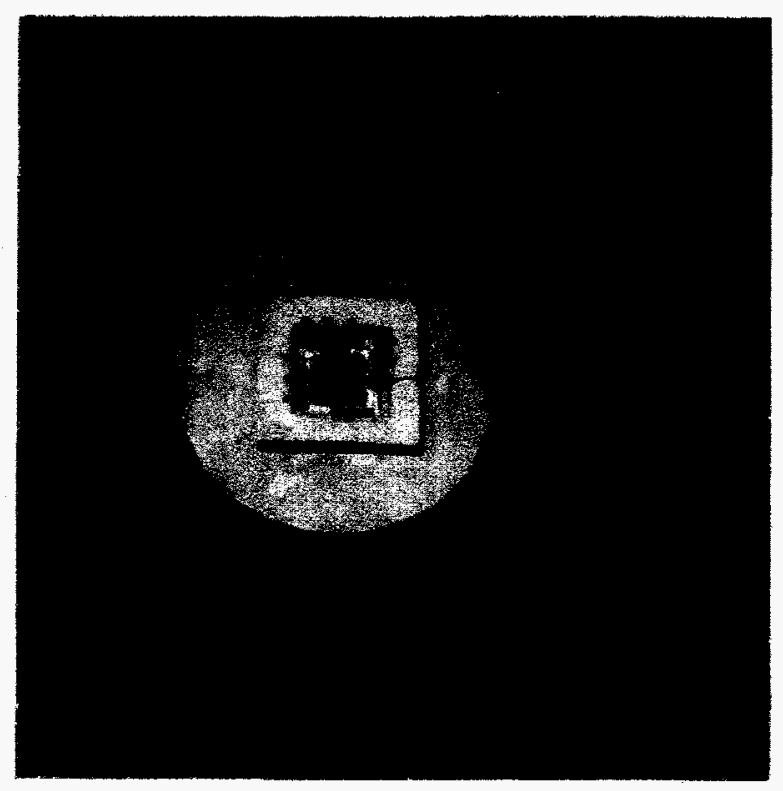

Figure 4.4 Partial Cell Assembly - Configuration 3. 


\subsubsection{Initial Visual Inspection of Typical Cell Assembly}

Configuration 1: In general, the cell assemblies (CA-80 thru 84) looked good. The base of the SOEs had a slight lip that protruded inward in a way so as to reflect a small portion of light that should impinge on the cell. This lip was caused by the stamping process of the turret punch tool/press. There was some excess solder around the periphery of the cells. On a couple of the cell assemblies, there was lack of the adhesive on the small section of the periphery of the heat spreader. This could allow debris to accumulate and cause a failure in the Hi-pot test. There was discoloration on some of the cells, indicating some solder flux had probably run onto the cell active area and was not cleaned off.

Configuration 2: The bottom contact used was a continuous strip of copper. Solder void areas were observed on the periphery of several of the contacts. Since the total area of these solder bonds are large, these voids did not appear to be very significant. Also, the bond was between two copper surfaces (and not dissimilar materials); thus, the thermal mismatch stresses were not present. The causes for bond failure would include improper wetting or presence of large voids. To improve the wetting, proper degreasing and etching is required before soldering. To minimize the presence of large voids, 0.037 -inch holes were made in the bottom contact as shown in Figure 2.2. These holes provided a path for removal of the spent flux (gases) and also aided in the visual inspection of the solder bond.

Configuration 3: Visual inspection of these three cell assemblies revealed only a minor defect. This defect, as per Sandia's opinion, was the presence of excess solder around the periphery of the cells. In SKI's opinion, this excess solder is acceptable if it does not wick up and short the PV cell. This problem is avoided if the copper surface is appropriately prepared so that its surface tension is high. The solar cells used for these samples appeared to be textured.

\subsubsection{Initial X-Ray and Ultrasound Results}

Radiographic pictures were taken of all the configuration 1 and 3 cell assemblies. A careful review of all these $x$-ray pictures did not show any large void areas in the cell/heat-spreader solder bond. Generally, the x-ray pictures indicated presence of a fine dispersion of many small voids in all the cell assemblies. The ultrasound pictures were more revealing of the solder bond. Ultrasound pictures for configuration 1 are presented in Figures 4.5 to 4.9. The pictures (originals in color) are obtained by reflection-type ultrasonic evaluation. The voids are indicated by the white boundaries with white or dark interiors (on black and white copies). The configuration 3 ultrasound pictures, Figure 4.10, are transmission-type ultrasound pictures. In the three pictures, the black regions indicate void areas. Large voids are indicated on the three cell assemblies. The voids seem to be more pronounced in the center of the cell as opposed to the periphery where the top interconnects are attached. The transmissiontype ultrasound pictures of configuration 2 samples are shown in Figure 4.11. They 


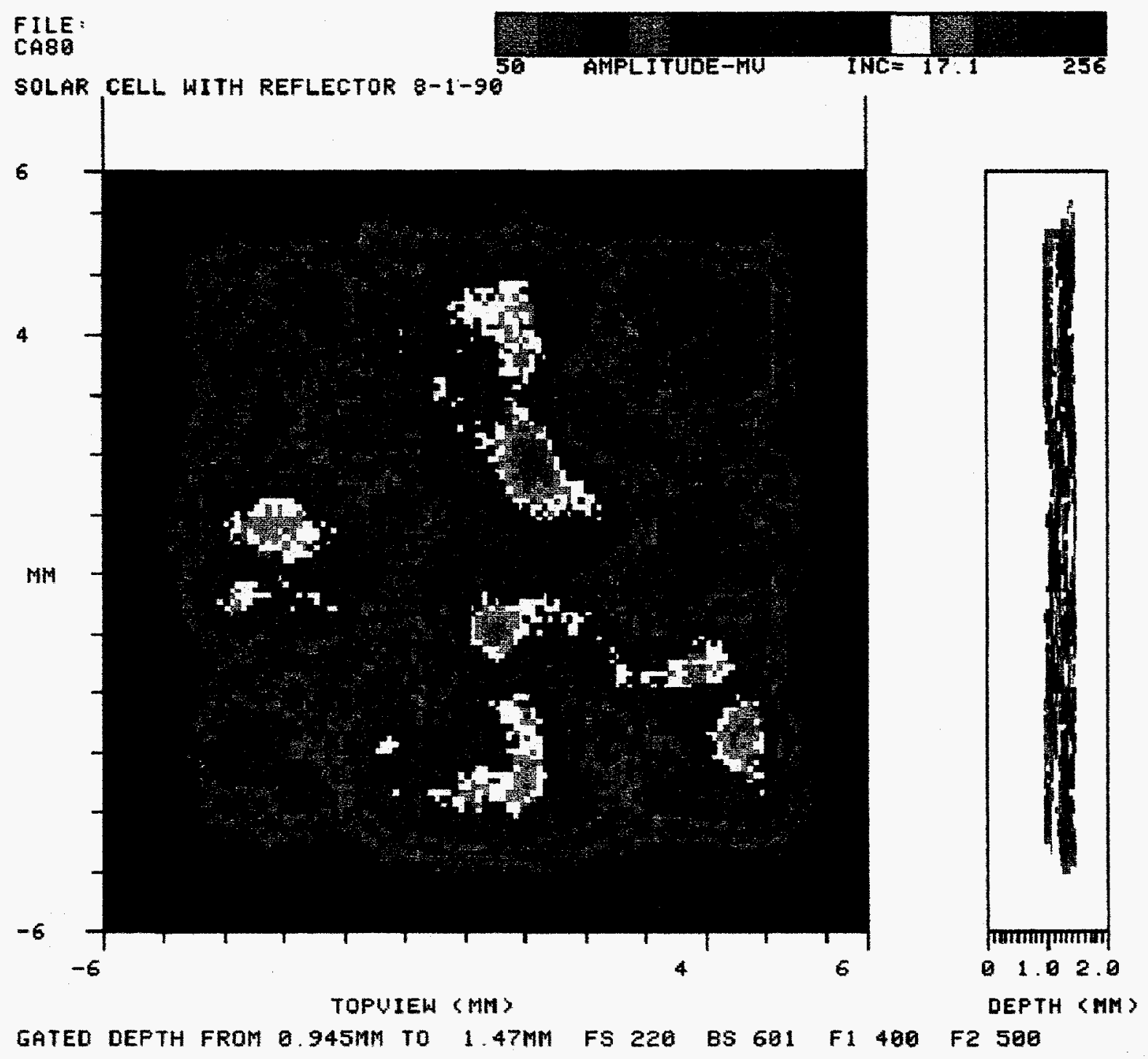

Figure 4.5 Initial Reflecting Ultrasound Picture, CA-80. 


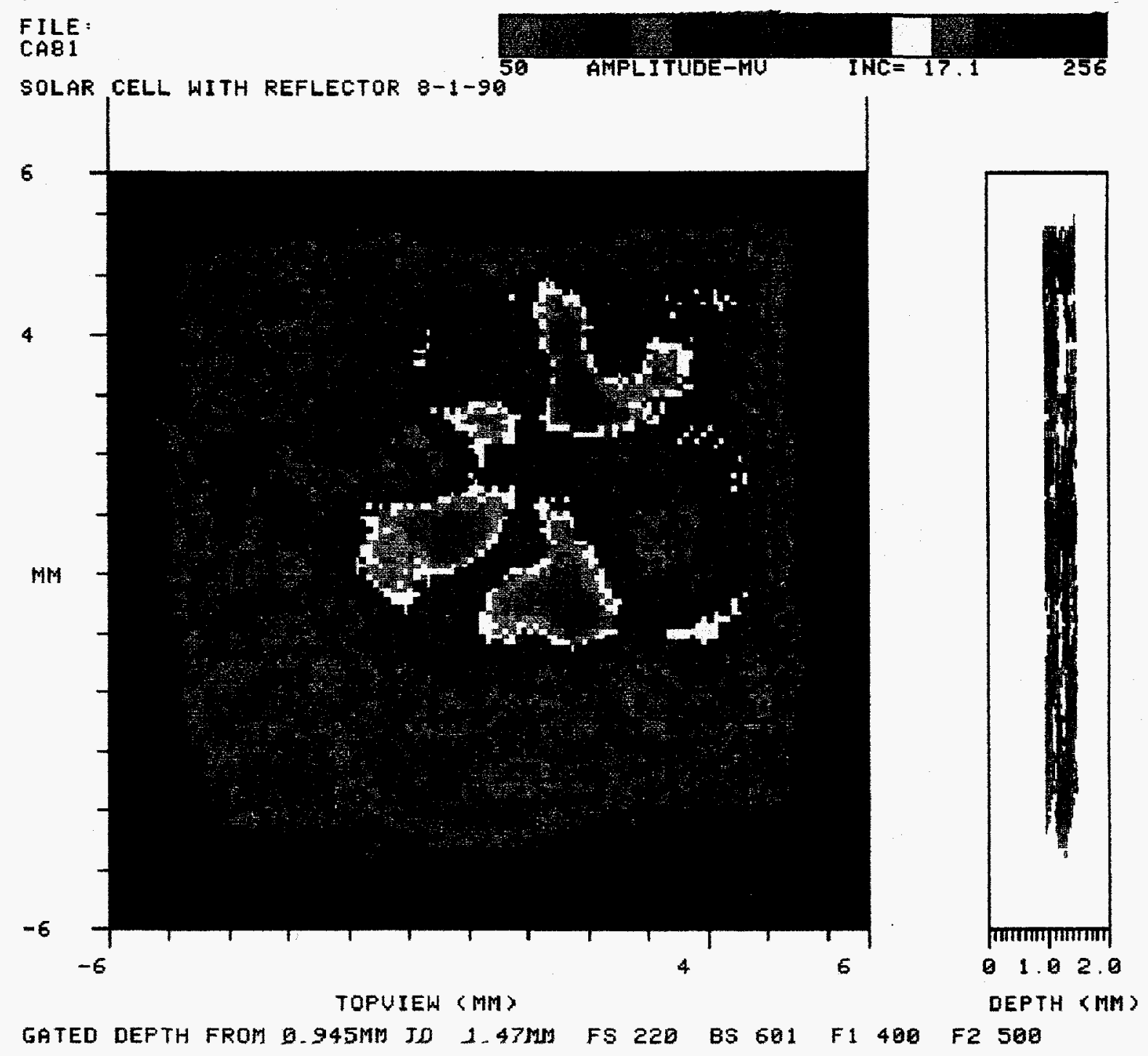

Figure 4.6 Initial Reflecting Ultrasound Picture, CA-81. 


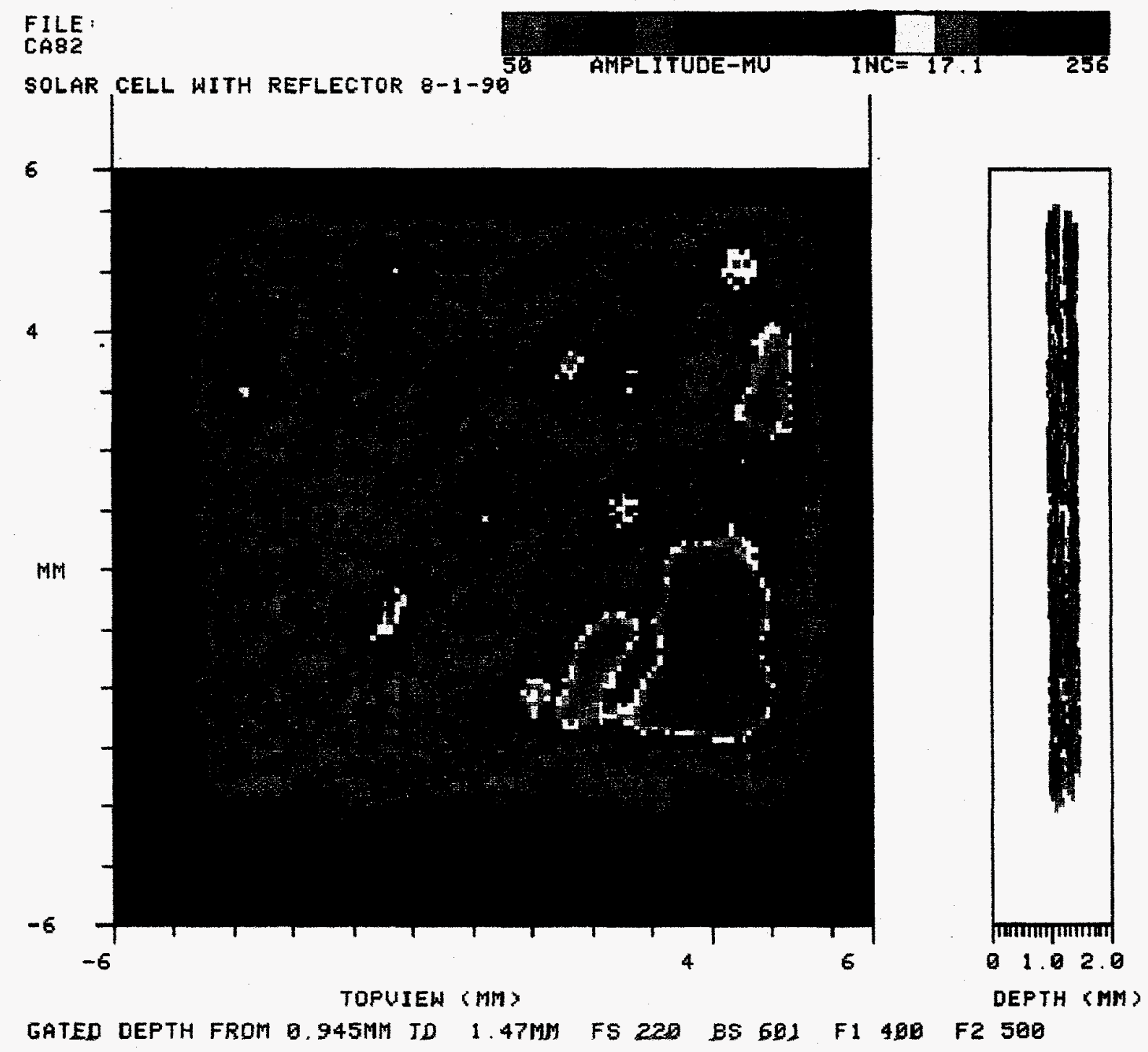

Figure 4.7 Initial Reflecting Ultrasound Picture, CA-82. 


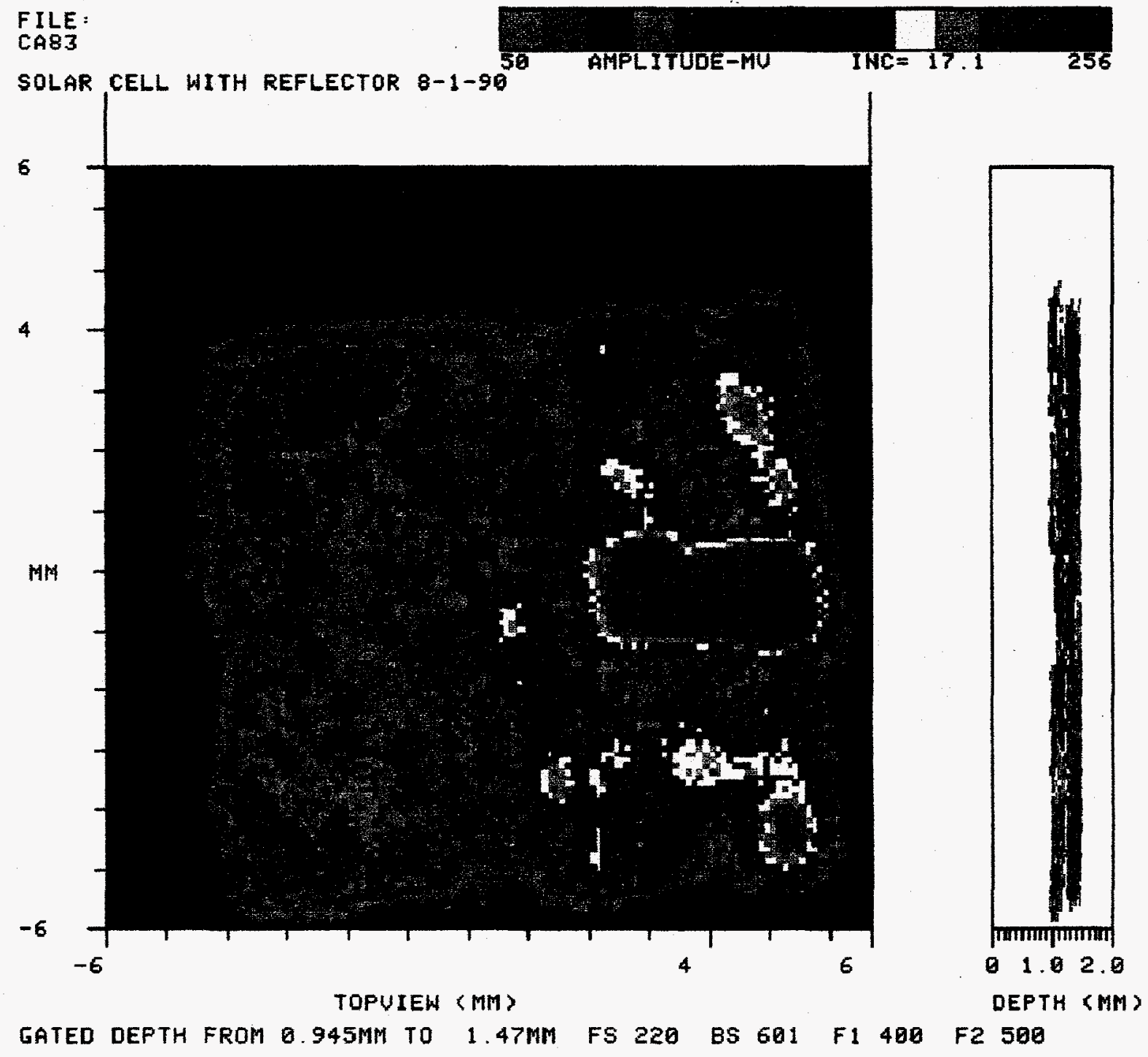

Figure 4.8 Initial Reflecting Ultrasound Picture, CA-83. 


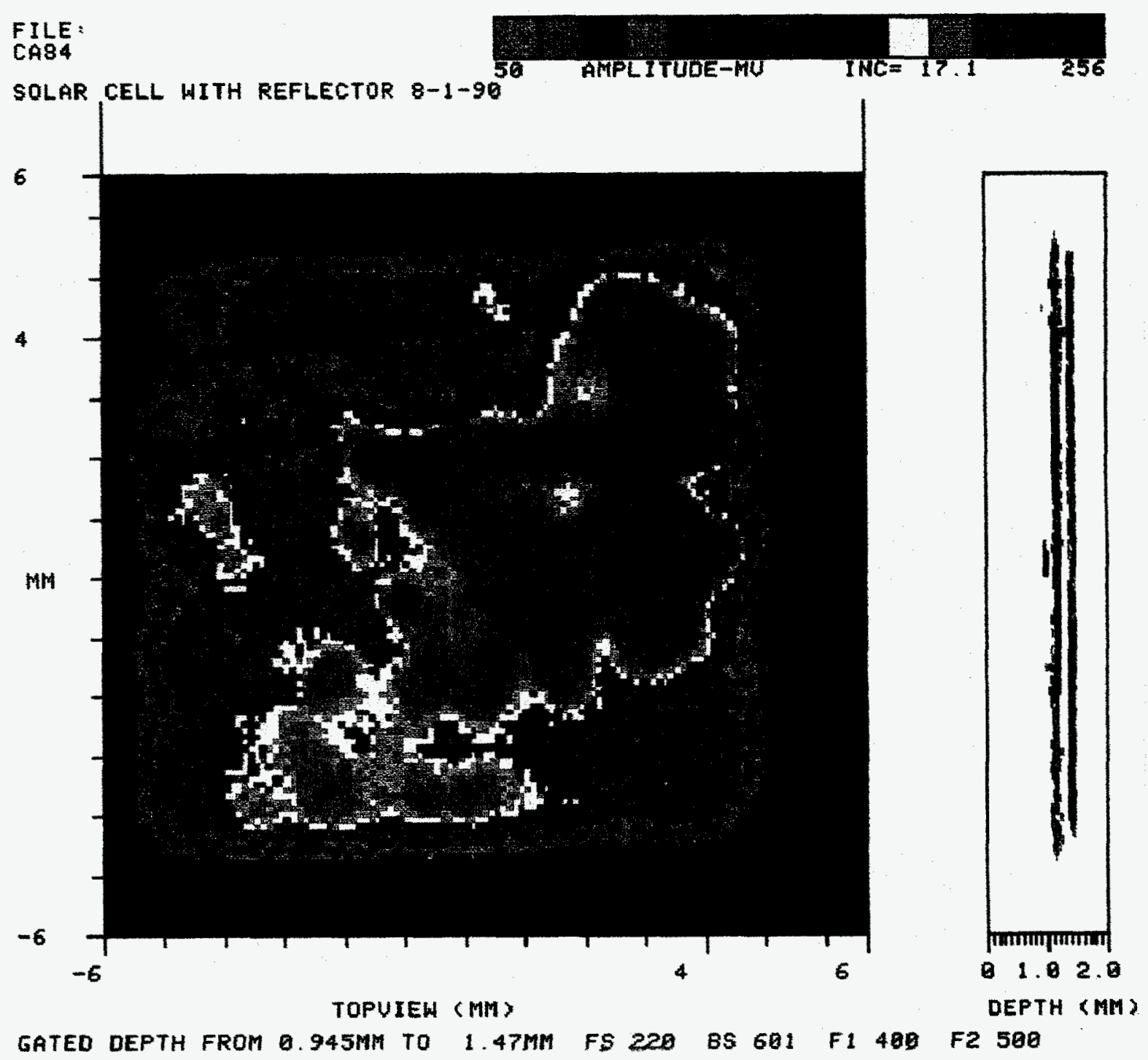

Figure 4.9 Initial Reflecting Ultrasound Picture, CA-84. 
$.25 \mathrm{inch} / \mathrm{div}$

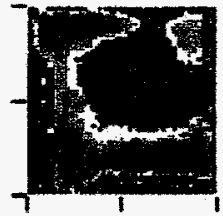

475

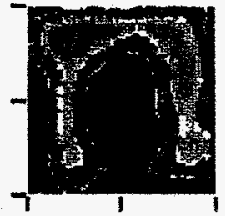

$\$ 76$

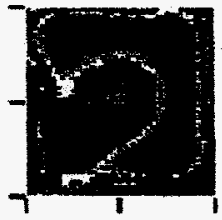

$\$ 77$

$3 D B$ Attenuation

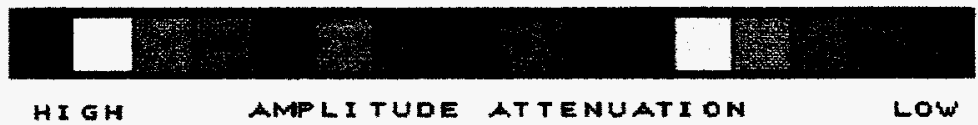

SKI Subcell Assembly

Heat Spreader Cell Top Interconnect

Figure 4.10 Initial Transmitting Ultrasound Pictures

Partial Cell Assemblies CA-75, 76, \& 77.

125 inch $/$ div

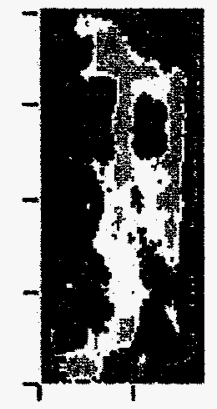

$\# 2$

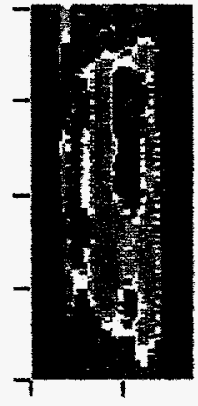

\#2A

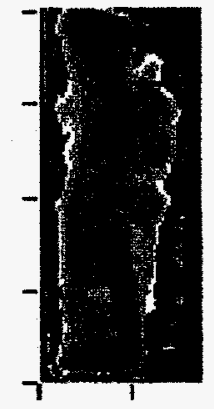

$\$ 4$

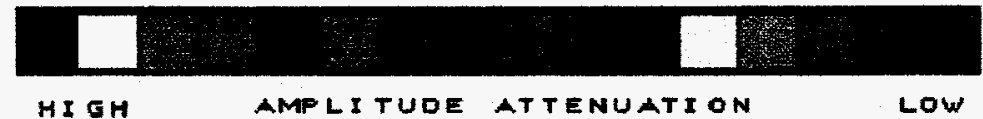

SKI Cell Assembly Intercomnect

Intercomnect rheat Spreader Solder Bond Figure 4.11 Initial Transmitting Ultrasound Pictures

Partial Cell Assemblies CA-2, 2A, \& 4. 
show that CA-2 has large areas of voids or weak solder bonds. Only cell assemblies CA-2A and CA-4 had good solder bonds.

From the various ultrasonic results, it became apparent that the solder bond had to be significantly more continuous, and minimization of the voids is critical. An appropriate combination of the following factors and their fine tuning are likely to lead to higher quality, large-area solder bonds:

*Solder type,

*Solder form,

*Surface preparation procedure,

*Selection of fluxes,

*Intermediate soldering steps,

*Soldering temperature,

*Soldering time span, and

*Tooling modifications.

\subsubsection{Initial Electrical and Hi-Pot Tests}

The configuration 1 and 3 cell assemblies were electrically tested in the Photovoltaic Device Measurement Laboratory (PDML) at Sandia, and the results of these tests are included in Figure 4.12. The efficiencies in the figure for configuration 1 were high because the cell assemblies included the SOEs, which have a concentration ratio of a little over $2 X$. The concentration was not considered in the efficiency calculation. It was to be used as comparison data to that taken in a like manner after the environmental tests were completed. The fill factor for all these cell assemblies was 0.708 to 0.712 at a concentration of about 250 suns. They were 19 to $21 \%$ efficient. The maximum power from the three PV cell assemblies was about 5.5 watts. All the measurements were performed at 250 suns and $25^{\circ} \mathrm{C}$. Thus, from the electrical performance aspects, all the cell assemblies performed well at concentration.

The cell assemblies of configuration 1 were hi-pot tested. All five of the cell assemblies passed the one-minute, 2200-volt hi-pot test with no observable leakage current. This test was performed at SKI and Sandia.

\subsubsection{Environmental Tests}

The cell assemblies were subjected to the temperature shock and humidity/freeze cycles as shown in Table 4.1. 
Cell 18: SKI-Ch-e4

Arte- $1.063 \mathrm{~Bq}$. CM

One sun current=7.710E-e2 Anps

One sun JsC=?.253E-82 naperCMA2

\begin{tabular}{|c|c|c|c|c|c|c|c|c|}
\hline CONC & EFF & YOC & $18 \mathrm{C}$ & $F F$ & YKP & IMP & $\begin{array}{l}\text { PnX } \\
\text { PuR } \\
\end{array}$ & TEMP \\
\hline $\begin{array}{r}76.60 \\
16.55 \\
124.10\end{array}$ & $\begin{array}{l}49.35 \\
39.18 \\
38.48\end{array}$ & $\begin{array}{l}.726 \\
.731 \\
.733\end{array}$ & $\begin{array}{r}5.906 \\
7.444 \\
.797\end{array}$ & $\begin{array}{l}.766 \\
.739 \\
.714\end{array}$ & $\begin{array}{l}.589 \\
.577 \\
.567\end{array}$ & $\begin{array}{l}5.581 \\
6.969 \\
0.229\end{array}$ & $\begin{array}{l}3.286 \\
4.021 \\
4.699\end{array}$ & $\begin{array}{l}24.9 \\
24.9 \\
24.8\end{array}$ \\
\hline
\end{tabular}

Call Id: SKI-CA-B3

Area" $2.063 \mathrm{Sq}$. Ch

One sun current $=7.653 E-92$ Anps

One sun Jec=7.199E-s2 Aaps/CMA2

\begin{tabular}{|c|c|c|c|c|c|c|c|c|}
\hline & & & & & & & GAX & \\
\hline $\begin{array}{r}\text { CONC } \\
55.36 \\
131.27\end{array}$ & $\begin{array}{l}\text { EPr } \\
1.10 \\
48.87 \\
18.34\end{array}$ & $\begin{array}{l}.717 \\
.723 \\
.727\end{array}$ & $\begin{array}{l}182 \\
5.768 \\
7.310 \\
.315\end{array}$ & $\begin{array}{l}.796 \\
.786 \\
.775\end{array}$ & $\begin{array}{l}.684 \\
.681 \\
.594\end{array}$ & $\begin{array}{l}5.451 \\
6.988 \\
. .068\end{array}$ & $\begin{array}{l}7.293 \\
4.150 \\
4.795\end{array}$ & $\begin{array}{l}124.9 \\
24.9 \\
24.9\end{array}$ \\
\hline
\end{tabular}

Cell Id: sKI-Ch-82

Rrean 1.063 Sa. Cr

One sun current=8.247E-e2 Amps

One sun Jee=7.758E-L2 nape/CHA2

\begin{tabular}{rllllllll} 
COHC & EFF & YOC & ISC & FF & YHP & IMP & MAX & TEHP \\
\hline 75.84 & 43.43 & .718 & 6.254 & .779 & .599 & 5.846 & 3.581 & 24.9 \\
96.28 & 43.05 & .724 & 7.948 & .766 & .594 & 7.413 & 1.486 & 24.9 \\
113.38 & 42.32 & .727 & 9.350 & .754 & .389 & 1.698 & 5.223 & 24.9
\end{tabular}

C+II Id: SKI-CA-si

Area $8.063 \mathrm{Gq}$. CM

One sun curreni $=7.543 E-92$ haps

One sun Jse $=7$. Q96E-12 Alps $\mathrm{CH}$-2

\begin{tabular}{|c|c|c|c|c|c|c|c|c|}
\hline сонс & EFF & YOC & ISC & $F F$ & YKP & I MP & $\begin{array}{l}\text { MAX } \\
\text { PHR }\end{array}$ & TEMP \\
\hline $\begin{array}{r}75.72 \\
96.75 \\
114.68\end{array}$ & $\begin{array}{l}48.27 \\
40.84 \\
39.73\end{array}$ & $\begin{array}{l}.716 \\
.722 \\
.725\end{array}$ & $\begin{array}{l}5.712 \\
7.298 \\
0.650\end{array}$ & $\begin{array}{l}.793 \\
.782 \\
.772\end{array}$ & $\begin{array}{r}.608 \\
.597 \\
.594\end{array}$ & $\begin{array}{l}5.480 \\
6.892 \\
6.149\end{array}$ & $\begin{array}{l}3.261 \\
4.218 \\
4.843\end{array}$ & $\begin{array}{l}24.9 \\
25.9 \\
25.9\end{array}$ \\
\hline
\end{tabular}

Cell Id: 8KI-CA-8e

Arte $=1.063 \mathrm{Sa}$. Ch

One sun current=7.05eE-e2 Aeps

One wun Jaew6.632E-82 Anps/CMA2

\begin{tabular}{|c|c|c|c|c|c|c|c|c|}
\hline cone & EFF & & & $F F$ & VAP & & $\begin{array}{l}\text { WAX } \\
\text { PHR }\end{array}$ & TEMP \\
\hline $\begin{array}{r}74.48 \\
44.79 \\
112.32\end{array}$ & $\begin{array}{l}38.55 \\
28.47 \\
88.32\end{array}$ & $\begin{array}{l}.723 \\
.729 \\
.732\end{array}$ & $\begin{array}{l}5.251 \\
6.683 \\
7.648\end{array}$ & $\begin{array}{l}.894 \\
.796 \\
.790\end{array}$ & $\begin{array}{l}.615 \\
.614 \\
.512\end{array}$ & $\begin{array}{l}4.962 \\
6.312 \\
7.418\end{array}$ & $\begin{array}{l}3.052 \\
3.977 \\
4.535\end{array}$ & $\begin{array}{l}24.9 \\
24.9 \\
24.9\end{array}$ \\
\hline
\end{tabular}

Configuration 1

Cell Id: 8KI-CA-75

Area $1.063 \mathrm{Sa}$. CM

One sun current-4.230E-12 Aleps

One sun JsE=3.979E-02 Anps, CHA2

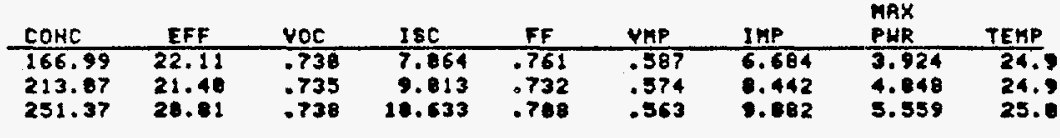

C+11 Id: SKI-CA-76

Area: $1.063 \mathrm{sa} . \mathrm{CH}$

One cun current=3.992E-82 Aups

One un Jse=3.755E-82 Aepscena?

\begin{tabular}{|c|c|c|c|c|c|c|c|c|}
\hline CONC & EFF & VOC & IsC & $F F$ & VMP & IMP & $\begin{array}{l}\text { mAX } \\
\text { PHR }\end{array}$ & TEKP \\
\hline $\begin{array}{l}171.29 \\
216.99 \\
256.98\end{array}$ & $\begin{array}{l}20.75 \\
28.27 \\
19.87\end{array}$ & $\begin{array}{l}.724 \\
.727 \\
.731\end{array}$ & $\begin{array}{r}6.838 \\
8.662 \\
10.252\end{array}$ & $\begin{array}{l}.764 \\
.743 \\
.724\end{array}$ & $\begin{array}{r}.586 \\
.575 \\
.563\end{array}$ & $\begin{array}{l}6.448 \\
6.137 \\
.637\end{array}$ & $\begin{array}{l}3.779 \\
4.676 \\
5.423\end{array}$ & $\begin{array}{l}24.9 \\
24.0 \\
35.9\end{array}$ \\
\hline
\end{tabular}

C+11 Id: SKI-CA-77

Arean $1.063 \mathrm{Sa}, \mathrm{CH}$

Ore sun curronim4.298E-02 Anps

One sun Jec=4.036E-2 nape 2 CHA2

\begin{tabular}{|c|c|c|c|c|c|c|c|c|}
\hline $\begin{array}{l}\text { CONC } \\
163.47 \\
206.98 \\
246.83\end{array}$ & $\begin{array}{c}\text { EFF } \\
22.41 \\
21.78 \\
21.16\end{array}$ & $\begin{array}{l}V D C \\
.731 \\
.735 \\
.737\end{array}$ & 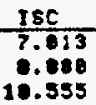 & $\begin{array}{l}F F \\
.759 \\
.734 \\
.712\end{array}$ & $\begin{array}{l}\text { UMP } \\
.598 \\
.575 \\
.564\end{array}$ & $\begin{array}{l}\text { IMP } \\
6.595 \\
0.335 \\
0.017\end{array}$ & $\begin{array}{l}\text { PHR } \\
3.894 \\
4.791 \\
5.535\end{array}$ & $\begin{array}{l}\text { TEMP } \\
24.9 \\
24.9 \\
24.9\end{array}$ \\
\hline
\end{tabular}

\section{Configuration 3}

Figure 4.12 Initial Electrical Characterization Data of Cell Assemblies. 


\section{Table 4.1. Environmental Test Schedule, First Group}

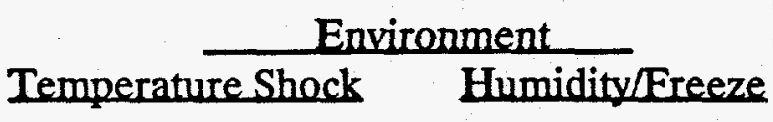

Configuration

\begin{tabular}{c} 
CANumbers \\
\hline $81 \& 82$ \\
$83 \& 84$ \\
$2,2 A \& 4$ \\
$75-77$
\end{tabular}

\begin{tabular}{c} 
(Cycles) \\
\hline 250 \\
60 \\
250 \\
250
\end{tabular}

(Cycles)

1

1

2

3

75-77

The resulting cell assemblies had some delamination. During the cycling test, CA-76 and CA-81 delaminated at the cell/heat spreader interface. The PV cell in cell assembly CA-82 broke (cracked). Visual observation revealed the separation of some regions of the PV cell from the heat spreader. Shortly after removal of cell assemblies CA-77 and CA-83, the PV cells separated from the heat spreader. During the visual inspection, the PV cell on CA-84 broke because most of it had also delaminated. The back sides of the PV cell and the solder zones on the heat spreader correspond to the bad solder areas as indicated by the ultrasonic pictures. Most often the poor solder bonds were in the central region. We think this is due to the entrapment of the flux volatiles during the heating process.

The solder bonds between the PV cell and the top contacts were still bonded after the cycling. These bonds were visually unchanged even for the cell assemblies where the cells had delaminated. In spite of the significant coefficient of thermal expansion (CTE) mismatch between the silicon PV cell and copper top contact, no failure occurred. This was due to the strain-relief-type design of the eight legs of the top contact.

The SOE on the configuration 1 units were still firmly attached to the top contact after the thermal and humidity/freeze cycling.

The interface between the cell assembly heat spreader and the aluminum housing did not delaminate. The adhesive looked unchanged, however, the Tefzel film had linetype bulges all going in one direction. This indicates that the film had been stretched and not recovered in one direction during thermal cycling. The film did not show any rupture or break. This behavior can be explained because Tefzel is a dielectric film with orientation in one direction. The direction perpendicular to this orientation is stretchable. 
The configuration 2 cell assemblies survived the environmental exposure with no change in the bottom contact/heat-spreader solder bond.

For the configuration 3 samples, no physical damage was seen between the bottom contact and heat-spreader solder bond after environmental cycling. This should be expected because of the soldering between copper parts.

\subsubsection{Post-Environmental Cycling Evaluation}

One cell assembly (CA-75) was intact and subjected to the post-ultrasound test. The ultrasound pictures showed a large void under the cell after environmental cycling.

The ultrasound pictures in Figure 4.13 implied that all of the partial cell assemblies CA-2, CA-2A, and CA-4 experienced little change in the bottom contact/heatspreader solder bond. Prying under the bottom contact of the cell assembly CA-4, with a screw driver, led to the peeling up of the bottom contact. This indicates improper surface preparation and/or selection of flux.

The electrical isolation for the complete cell assemblies (configuration 1) measured acceptable. Thus, a post- cycling hi-pot test was performed. This test showed less than 1 micro amps leakage current on all four cell assemblies. This hi-pot test was performed on CA-83 and CA-84 within one hour of the time they were removed from the humidity/freeze cycling chamber.

Thus, in conclusion, the cell assemblies did not pass all the evaluation tests. The main deficiency was in the quality of the solder bond between the PV cell and the heat spreader. This area of processing needs more development. The electrical isolation scheme works well. The solder bonds between the PV cell and top contact held up with no degradation. The SOE attachment scheme worked well. There was no visible degradation of the reflective surface of the SOE. The solder bond between the bottom contact and the heat spreader had some voids.

\subsection{Second Set of Cell Assemblies for Evaluation}

The result of Sandia testing of the first group of cell assemblies delivered for evaluation suggested the main problem to be resolved was the solder bond between the PV cell and the copper heat spreader. The cell assemblies had passed all other requirements. Thus, SKI evaluated the causes of the failure and developed improved designs and processes in an attempt to eliminate the failures. We examined our tooling for the soldering of the cell assemblies. We determined that the weight used to hold the PV cell in position during the soldering operation was only in contact with the fingers of the top contact. Thus, the central region of the cell was not pressurized and could bulge (bow upwards) as the result of trapped solder flux gases. This led to no contact of the PV cell with the heat spreader, thus the presence of large central voids. 


\begin{tabular}{|c|c|c|c|}
\hline & & \multicolumn{2}{|c|}{ Environment } \\
\hline & & Temperature Shock & Humidity/Ereeze \\
\hline Configuration & CA Numbers & (Cycles) & (Cycles) \\
\hline 1 & $81 \& 82$ & 250 & - \\
\hline 1 & $83 \& 84$ & 60 & 10 \\
\hline 2 & $2,2 \mathrm{~A}, \& 4$ & 250 & - \\
\hline 3 & $75-77$ & 250 & - \\
\hline
\end{tabular}

The resulting cell assemblies had some delamination. During the cycling test, CA-76 and CA-81 delaminated at the cell/heat spreader interface. The PV cell in cell assembly CA-82 broke (cracked). Visual observation revealed the separation of some regions of the PV cell from the heat spreader. Shortly after removal of cell assemblies CA-77 and CA-83, the PV cells separated from the heat spreader. During the visual inspection, the PV cell on CA- 84 broke because most of it had also delaminated. The back sides of the PV cell and the solder zones on the heat spreader correspond to the bad solder areas as indicated by the ultrasonic pictures. Most often the poor solder bonds were in the central region. We think this is due to the entrapment of the flux volatiles during the heating process.

The solder bonds between the PV cell and the top contacts were still bonded after the cycling. These bonds were visually unchanged even for the cell assemblies where the cells had delaminated. In spite of the significant coefficient of thermal expansion (CTE) mismatch between the silicon PV cell and copper top contact, no failure occurred. This was due to the strain-relief-type design of the eight legs of the top contact.

The SOE on the configuration 1 units were still firmly attached to the top contact after the thermal and humidity/freeze cycling.

The interface between the cell assembly heat spreader and the aluminum housing did not delaminate. The adhesive looked unchanged, however, the Tefzel film had linetype bulges all going in one direction. This indicates that the film had been stretched and not recovered in one direction during thermal cycling. The film did not show any rupture or break. This behavior can be explained because Tefzel is a dielectric film with orientation in one direction. The direction perpendicular to this orientation is stretchable. 
$125 \mathrm{inch} / \mathrm{div}$

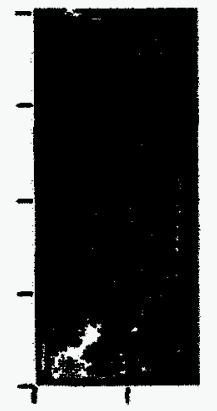

12

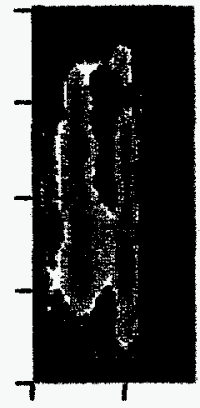

EZA

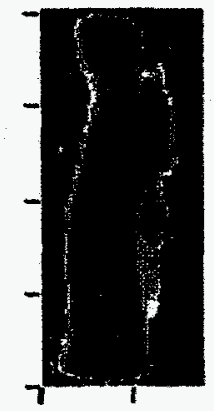

*4

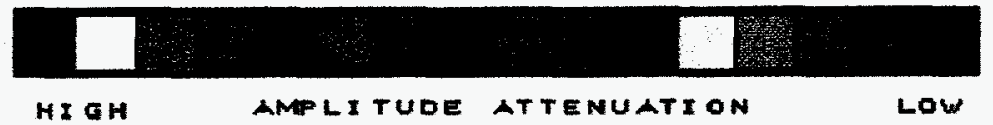

Figure 4.13 Final Transmitting Ultrasound Pictures

Partial Cell Assemblies CA-2, 2A, \& 4. 
Modifications were made to the solder fixture so as to apply pressure to the active portion of the PV cell during soldering. We also reduced the solder preform thickness from 0.001 inch to 0.0005 inch to minimize the excess solder around the periphery of the cell. We coined the heat spreaders to ensure that they were flat to within 0.0005 inch below the PV cell. Cleaning processes for the heat spreader were also improved. Also, five 0.037 -inch holes were added to the bottom contact as shown in Figure 2.2. This allowed the gases to escape during the soldering process and also provided a means for visually inspecting the bond quality. If all the holes were filled with reflow solder and the solder bond along the periphery was filled and continuous, the bond would appear to be acceptable.

Four new partial cell assemblies (CA-11B, CA-11C, CA-11D, and CA-11E) incorporating the features discussed above were fabricated. Careful visual inspection was performed. Also, $x$-rays were taken and then the cell assemblies were shipped to Sandia for evaluations. These assemblies were of similar configurations, as shown in Figure 4.4, with the addition of the bottom contact. Sandia planned to expose them to the full set of evaluation tests except for the hi-pot test. The results of these tests are described below.

\subsubsection{Initial Visual Examination}

The cell assemblies looked good. There was a small amount of excess solder around the periphery of the cells. The cell assemblies CA-11B and CA-11C had textured PV cells while the other two had untextured surfaces. The top contact fingers were slightly misaligned on the PV cells. All the solder bonds looked good. The anti-reflection (AR) coating on CA-11D was streaked, indicating residue of the rosin flux.

\subsubsection{Initial Electrical Characterization}

Initial electrical characterization was performed in the PDML at Sandia using the one-sun and flash testers. The flash test was performed at approximately 230 suns and $20 \%$ about this level. The 230 suns is the geometric concentration ratio (282) times the optical efficiency (80\%). A summary of these tests is given in Figure 4.14. A PDML standard cell (ASEC A73-1) was tested along with the cell assemblies. The position of the cells in the flash tester was carefully noted. The standard cell data and the positions were to be used to reposition the cell assemblies for the post environmental tests.

\subsubsection{Initial Ultrasound Pictures and X-rays}

$\mathrm{X}$-rays of the four CA-11 cell assemblies were taken by a local laboratory. These (x-rays) were observed by Sandia personnel at SKI and confirmed the SKI observations. SKI read the $x$-rays as showing only small voids in the solder interface. Sandia took transmission-type ultrasound pictures. They are shown in Figure 4.15. From these pictures, it was observed that there is a significant variation in the condition of the cell-to-heat spreader solder bond. Ultrasound of cell assembly CA-11D looked very uniform without voiding. Ultrasounds of cell assemblies CA-11C and CA-11E looked 
SEPT $20 \quad 1998 \quad 9: 14$ RM MST

Cell Id: SKI-CA-11B

Area $=1.863 \mathrm{Sq}$. CM

One sun current $=3.698 \mathrm{E}-02$ Rmps

One sun $J_{s c}=3.479 E-82$ Rmps/CMn2

\begin{tabular}{lllllllll} 
CONC & EFF & VOC & ISC & FF & UMP & IMP & PHR & TEMP \\
\hline 181.63 & 19.83 & .726 & 6.717 & .785 & .686 & 6.316 & 3.829 & 25.0 \\
227.78 & 19.66 & .731 & 8.423 & .773 & .599 & 7.949 & 4.759 & 24.9 \\
276.64 & 19.36 & .735 & 18.230 & .757 & .591 & 9.626 & 5.693 & 25.8
\end{tabular}

Cell Id: SKI-CA-11C

Area $=1.063 \mathrm{Sq} . \mathrm{CM}$

One sun current $=3.524 E-B 2$ Amps

One sun Isc $=3.315 E-02$ Amps/CMA2

\begin{tabular}{lllllllll} 
CONC & EFF & VOC & ISC & FF & UMP & IMP & PRX & TEMP \\
\hline 180.47 & 19.83 & .733 & 6.360 & .783 & .688 & 6.801 & 3.650 & 25.8 \\
225.11 & 18.73 & .738 & 7.933 & .766 & .682 & 7.448 & 4.483 & 25.0 \\
273.26 & 18.41 & .742 & 9.630 & .749 & .589 & 9.872 & 5.348 & 25.0
\end{tabular}

Cell Id: $S K I-C A-11 D$

Prea $=1.063 \mathrm{Sq}=\mathrm{CM}$

One sun current $=3.456 \mathrm{E}-\mathrm{B2}$ Amps

One sun $\mathrm{Jsc}=3.251 \mathrm{E}-\mathrm{B} 2$ Rimps $/ \mathrm{CM}^{\prime} 2$

\begin{tabular}{lllllllll} 
CONC & EFF & VOC & ISC & FF & UMP & IMP & MAX & TEMP \\
\hline 182.76 & 19.22 & .733 & 6.316 & .807 & .627 & 5.957 & 3.735 & 25.8 \\
230.83 & 19.89 & .738 & 7.950 & .796 & .621 & 7.522 & 4.669 & 24.9 \\
277.83 & 18.91 & .742 & 9.602 & .784 & .616 & 9.870 & 5.584 & 25.8
\end{tabular}

Cell Id: SKI-CA-11E

Area $=1.863 \mathrm{Sq} . \mathrm{CM}$

One sun current $=3.399 E-02$ Rimps

One sun Jse $=3.198 \mathrm{E}-82$ Rmps/CMA2

\begin{tabular}{lllllllll} 
CONC & EFF & VOC & ISC & FF & UMP & IMP & PWR & TEMP \\
\hline 185.18 & 19.88 & .736 & 6.294 & .811 & .629 & 5.974 & 3.756 & 25.8 \\
232.85 & 18.97 & .741 & 7.915 & .801 & .526 & 7.580 & 4.696 & 25.8 \\
284.84 & 18.87 & .746 & 9.682 & .792 & .624 & 9.164 & 5.715 & 25.8
\end{tabular}

CEl1 Id: RSEC AT3-1

Area $=1.808 \mathrm{Sq} . \mathrm{CM}$

One sun current $=2.990 E-02$ Rmps

One sun $J_{s c}=2.998 E-82$ Amps $/ \mathrm{CM}^{\prime} 2$

\begin{tabular}{lllllllll}
\multicolumn{1}{c}{ CONC } & EFF & VOC & ISC & FF & UMP & IMP & PAX & TEMP \\
\hline 173.78 & 18.95 & .750 & 5.196 & .805 & .634 & 4.946 & 3.136 & 24.9 \\
216.72 & 17.96 & .755 & 6.480 & .795 & .630 & 6.178 & 3.893 & 25.8 \\
261.13 & 17.87 & .760 & 7.888 & .786 & .627 & 7.445 & 4.665 & 25.0
\end{tabular}

Figure 4.14 Initial Electrical Characterization Data Cell Assemblies CA 11C, 11D, and 11E. 


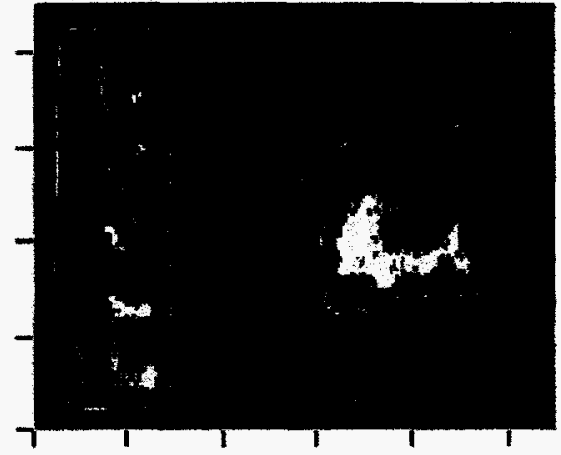

11B

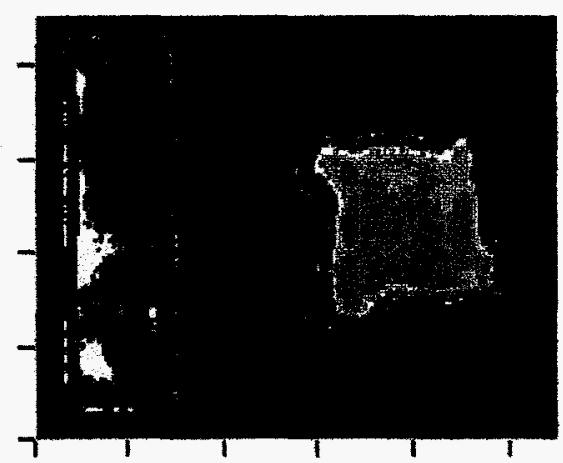

110

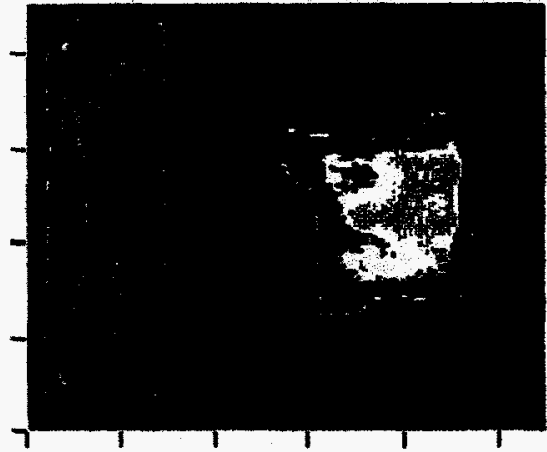

$11 \mathrm{C}$

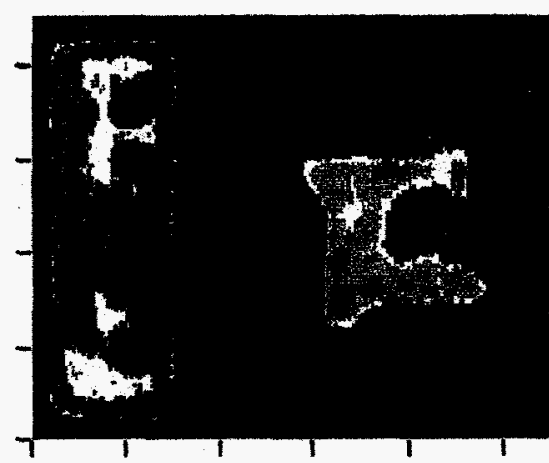

11E

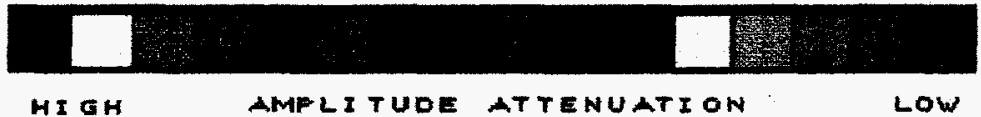

SKI Call Assenblies: Pre-Temperature Cycle

Figure 4.15 Initial Transmitting Ultrasound Pictures Cell Assemblies CA 11B through 11E. 
non-uniform with unacceptable void sizes. Ultrasound pictures of the cell assembly CA-11B looked poor. Based on previous results, it was anticipated that only cell assembly CA-11D would survive the environmental cycling tests. A solder bond with more than $10 \%$ void area is unacceptable as per the Sandia qualificaiton requirements.

\subsubsection{Environmental Cycling Tests}

The cell assemblies were subjected to thermal cycling and humidity/freeze cycles as shown in Table 4.2.

\begin{tabular}{|lcc|}
\hline & Table 4.2 Environmental Cycling & \\
Cell Assembly & $\begin{array}{c}\text { Temperature Shock } \\
\text { (Cycles) }\end{array}$ & $\begin{array}{c}\text { Humidity/Freeze } \\
\text { (Cycles) }\end{array}$ \\
\hline 11C \& 11E & 250 & -- \\
11B \& 11D & 60 & 10 \\
\hline
\end{tabular}

The selection of cell assemblies for a specific test was based on the ultrasound results. A good and a poor one was selected for each of the two different cycles. After the temperature shock exposure of $\mathrm{CA}-11 \mathrm{~B}$ and $\mathrm{CA}-11 \mathrm{D}$, the visual examination showed that on CA-11D the AR coating and some of the metallization had flaked off in one corner of the untextured cell. This flaking became worse after humidity/freeze cycling. No other visual defects were observed in any of the cell assemblies except for a slight discoloration of the copper as a result of the environmental exposures. A quick electrical test was performed to determine if the PV cells were active. When exposed to an incandescent light source, all cell assemblies produced a voltage between 0.5 and 0.6 volts. This indicated that the PV cells had not shorted.

\subsubsection{Post-Environmental Cycling Ultrasound Results}

Ultrasound pictures taken after the environmental exposures are presented in Figure 4.16. The bond in the cell assembly CA-11D was essentially unchanged, but the others exhibited delamination at the cell-to-heat-spreader interface. Clearly, the environmental exposure made the poor cell assemblies worse. The test results also showed that a good continuous solder bond survived the environmental exposures. Further fine tuning of the process should solve these problems. The bond between the heat spreader and the bottom contact survived the environmental exposure with no change in bond quality. 


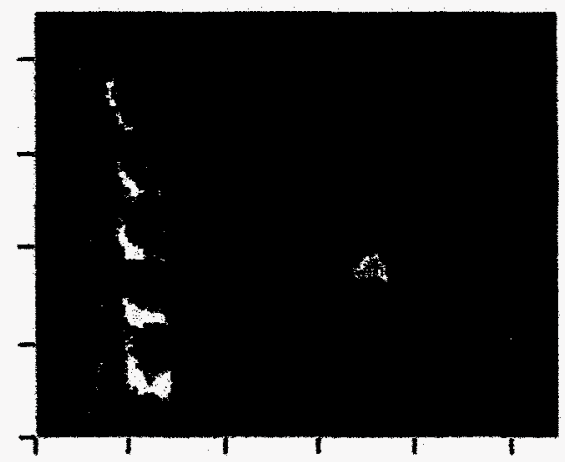

118

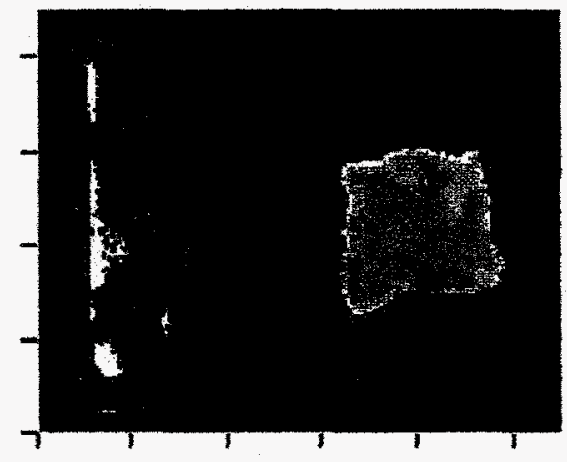

110

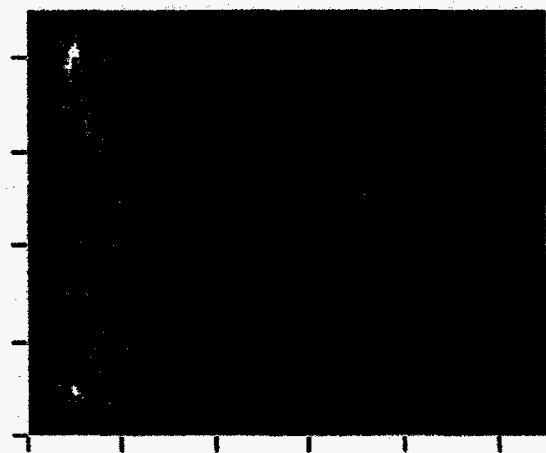

$11 \mathrm{C}$

.25 inch/div

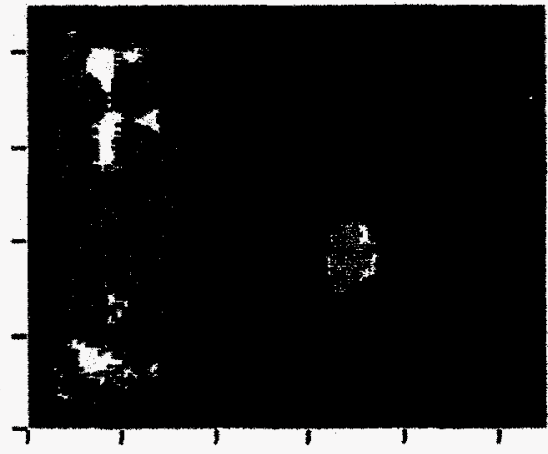

$11 \mathrm{E}$

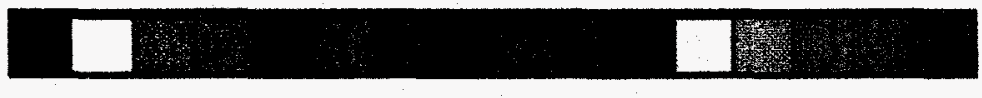

HIGH

AMPLITUDE ATTENUATION

Low

SKI Cell Assemblies: Post-Tenperature Cycling

Figure 4.16 Final Transmitting Ultrasound Pictures Cell Assemblies CA 11B through 11E. 


\subsubsection{Post Environmental Cycling Electrical Tests}

The above set of cell assemblies was recharacterized in the PDML, at SNLA, using the ASEC A73-1 standard cell to reposition the units at the same positions as the initial characterization. A summary of the test results is shown in Figure 4.17. A comparison of the before and after exposure electrical characterization is given in Table 4.3.

\section{Table 4.3 Pre \& Post Environmental Test Comparison Electrical Characterization Cell Assemblies CA 11B and 11E}

Cell

Assembly

Test

180

(\#)

Condition

CA 11B

Pre Env.

Post Env.

(\%)

Change

$\%$ Change $^{1}$

19.83

18.69

$-1.06$

$-5.34$

Cell Assembly Efficiency at Approx. Concentration (Suns)

CA $11 \mathrm{C}$

Pre Env.

19.03

18.64

$-0.39$

Change

$-2.05$

$225^{2}$

273

$\%$ Change $^{1}$

19.22

18.55

$-0.67$

$-3.64$

19.66

18.23

$-1.43$

$-7.27$

(\%)

CA 11D

Pre Env.

Post Env.

Change

$\%$ Change $^{1}$

18.73

18.33

$-0.40$

$-2.13$

19.36

17.68

$-1.69$

$-8.73$

CA $11 \mathrm{E}$

Pre Env.

19.08

19.09

18.41

17.95

$-0.46$

$-2.49$

Post Env.

18.83

Change

$-0.25$

18.43

18.91

$\%$ Change $^{1}$

$-1.31$

$-0.66$

18.22

$-0.69$

$-3.45$

$-3.62$

18.97

18.87

18.66

18.49

$-0.31$

$-0.38$

$-1.63$

$-2.01$

${ }_{1}^{1}$ The qualification document allows $8 \%$.

${ }^{2}$ Nominal use concentration based on a direct normal insolation of $1 \mathrm{~kW} / \mathrm{M}^{2}$ and an optical efficiency of $80 \%$. 


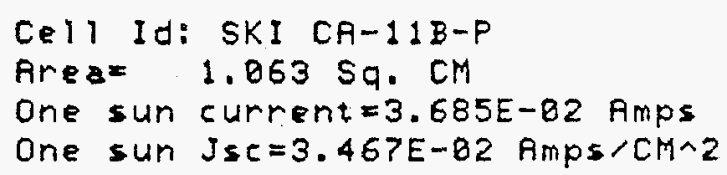

\begin{tabular}{lllllllll} 
CONC & EFF & VOC & ISC & FF & UMP & IMP & PAX \\
\hline 182.53 & 18.69 & .721 & 6.726 & .748 & .576 & 6.296 & 3.626 & TEMP \\
229.48 & 18.23 & .727 & 8.453 & .724 & .564 & 7.876 & 4.445 & 24.7 \\
278.52 & 17.68 & .731 & 18.263 & .698 & .552 & 9.473 & 5.234 & 24.8
\end{tabular}

Cell Id: SKI CA-11C-P

firea $=1.063 \mathrm{sq} . \mathrm{CM}$

One sun current $=3.489 E-82$ Amps

One sun Jse $=3.282 E-82$ Amps $/ \mathrm{CM}^{\prime} 2$

\begin{tabular}{|c|c|c|c|c|c|c|c|c|}
\hline CONC & EFF & YOC & ISC & FF & UMP & IMP & $\begin{array}{l}\text { MRX } \\
\text { PWR }\end{array}$ & TEMP \\
\hline 181.69 & 18.64 & .733 & 6.339 & .775 & .682 & 5.975 & 3.608 & 25.8 \\
\hline 226 & 18.33 & .736 & 7.908 & .759 & .593 & 7.442 & 4.413 & 24.5 \\
\hline & 17.95 & .748 & 9.683 & .739 & .582 & 9.821 & 5.252 & 4.8 \\
\hline
\end{tabular}

Cell Id: SKI CA-11D-P

Area $=1.063 \mathrm{Sq} \cdot \mathrm{CM}$

One sun current $=3.375 E-82$ Amps

One sun $J_{s C}=3.175 E-02$ Amps $/ \mathrm{CM}^{\wedge} 2$

\begin{tabular}{|c|c|c|c|c|c|c|c|c|}
\hline & & & & & & & MAX & \\
\hline CONC & EFF & yoc & $15 C$ & $F F$ & YMP & IMP & PWR & TEMP \\
\hline 182.43 & 18.55 & .728 & $6.15 ?$ & .803 & .615 & 5.849 & 3.597 & 25.6 \\
\hline 230.59 & 18.43 & .733 & 7.782 & .792 & .613 & 7.373 & 4.517 & 24.9 \\
\hline 280.00 & 18.22 & .738 & 9.458 & .777 & .687 & 8.926 & 5.423 & 24.8 \\
\hline
\end{tabular}

Cell Id: SKI CR-11E-P

Area $=1.063 \mathrm{sq} . \mathrm{CM}$

One sun current $=3.387 \mathrm{E}-02$ Amps

One sun $J s C=3.186 E-82$ Amps/CM^2

\begin{tabular}{lllllllll} 
CONC & EFF & YOC & ISC & FF & YMP & IMP & MAX & TEMP \\
\hline 190.46 & 18.83 & .735 & 6.451 & .804 & .622 & 6.126 & 3.811 & 25.8 \\
239.27 & 18.66 & .748 & 8.184 & .791 & .620 & 7.657 & 4.746 & 25.1 \\
288.79 & 18.49 & .743 & 9.781 & .781 & .614 & 9.243 & 5.676 & 25.8
\end{tabular}

CE) Id: ASEC RP3-1

Are $=1.000 \mathrm{SQ} . \mathrm{cm}$

One sun current $=2.979 E-02$ Rmps

One sun $\mathrm{Jsc}=2.979 \mathrm{E}-82$ AMps/CMA2

\begin{tabular}{|c|c|c|c|c|c|c|c|c|}
\hline & & & & & & & $\operatorname{MAX}$ & \\
\hline CONC & EFF & VOC & I SC & FF & $\angle M P$ & IMP & PWR & TEMP \\
\hline 176.66 & 17.88 & .750 & 5.263 & .800 & .631 & 5.003 & 3.159 & 25.8 \\
\hline 220.70 & 17.73 & .756 & 6.575 & .788 & .628 & 6.235 & 3.913 & 25.8 \\
\hline 264.50 & 17.59 & .759 & 7.879 & .778 & .622 & 7.476 & 4.652 & 25.8 \\
\hline
\end{tabular}

\section{Figure 4.17 Final Electrical Characterization Data Cell Assemblies 11B thru 11E.}


From the data in Table 4.3, it is evident that at the nominal concentration, all cell assemblies passed the electrical characterization evaluation test requirement that allows an $8 \%$ drop in efficiency. The fill factor dropped only for the cell assemblies with poor solder bonds.

Thus, one cell assembly passed all the environmental cycling tests. Three cell assemblies passed the electrical characterization tests, but failed the qualifications for continuous solder bond. All other critical areas of the cell assembly (i.e., SOE mounting, top contact attachment, bottom contact solder bond, dielectric stand-off) survived the evaluation tests. Although there were some successes, the cell assembly design failed the evaluation. The evaluation pointed out areas where the design needed improvement. 



\subsection{Module Evaluation}

A mock module was fabricated for Sandia environmental testing of the SKI module design. This mock module was subjected to the humidity/freeze environmental cycling to assess the performance of the lens mounting design. Another objective was to subject the module to the Sandia standard rain test after the humidity/freeze cycling and check for water leaks. Figure 5.1 shows the mock module under rain test (5).

The module consists of aluminum housing with two 0.125 -inch-thick plano-plano acrylic sheets substituted for the two lens parquets. There is no sealant along the length of either the edge clips or the lens partition clip. Silicone RTV is used to only seal the mitered corners of the clips.

The module after being received at Sandia was first visually inspected. The two acrylic sheets, simulating the lens parquets, and the mounting clips were scribed at various places. These scribes were used for referencing the movements and deforming of the acrylic sheet. Also pairs of scribe marks were made at various places in the central region of the acrylic sheets and were accurately measured. They also measured the vertical displacements of the acrylic sheets at various locations. The intent of this study was to use the deformation data to evaluate and modify the module design and/or the mounting clip design to minimize lens distortion and water leakage.

The module was subjected to total of 10 humidity/freeze cycles as specified in the module qualification document (3), and shown in Figure 5.2. The module was retrieved from the cycling chamber after 4 cycles, measured for various scribe mark displacements and then placed in the chamber again to complete the rest of the cycles. The slippage/expansion of the acrylic sheets after 4 cycles varied from zero to 0.06 inch when measured with reference to the various scribe marks on the clips. The vertical displacements from the original plane, varied as much as $0.20 \mathrm{inch}$. Some rotation of the acrylic sheet was also observed. This suggests that two alignment pins are inadequate for holding the lens parquet in proper alignment. A four-pin scheme is to be investigated.

The slippage/expansion of the acrylic sheets after 10 cycles ranged from zero to 0.080 inch with reference to the scribes on the clips. Figure 5.3 shows the module (plan view and end view), the position of the scribes, the displacements in the plane of the acrylic sheets, and the vertical displacements are also tabulated. The vertical displacements, from the original plane, ranged as much as +0.20 inch and -0.25 inch. To minimize this deflection in future modules, we plan to use American Optical injectionmolded $2 \times 2$ lens parquets, which are approximately 0.25 inch in effective thickness including facets. Thus, working with $1 / 3$ the lens parquet length and twice the thickness, it is Sandia's opinion that the lens bowing will be significantly less, if any, as a result of the humidity/freeze cycling. 


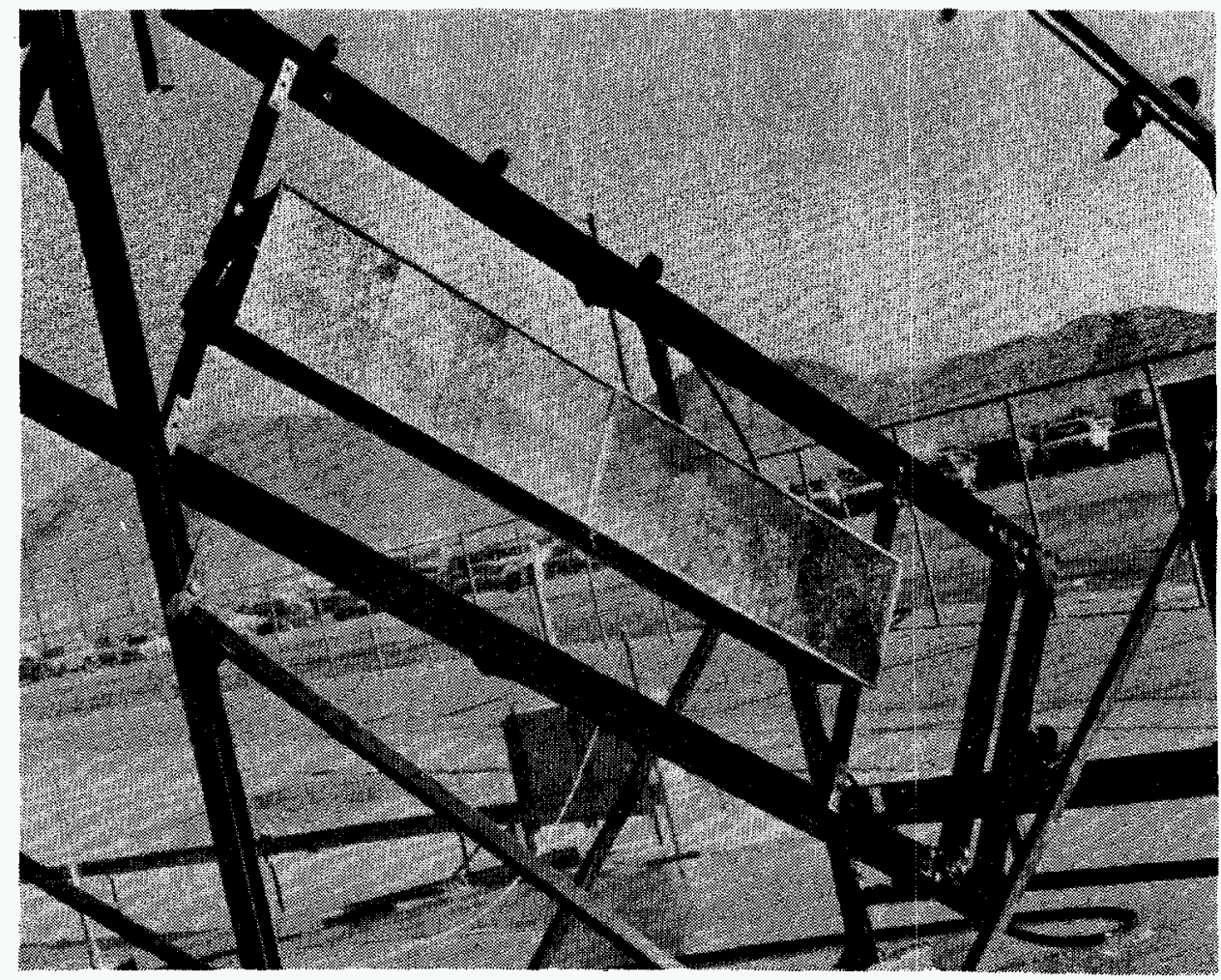

Figure 5.1 Mock Module Under Rain Test.

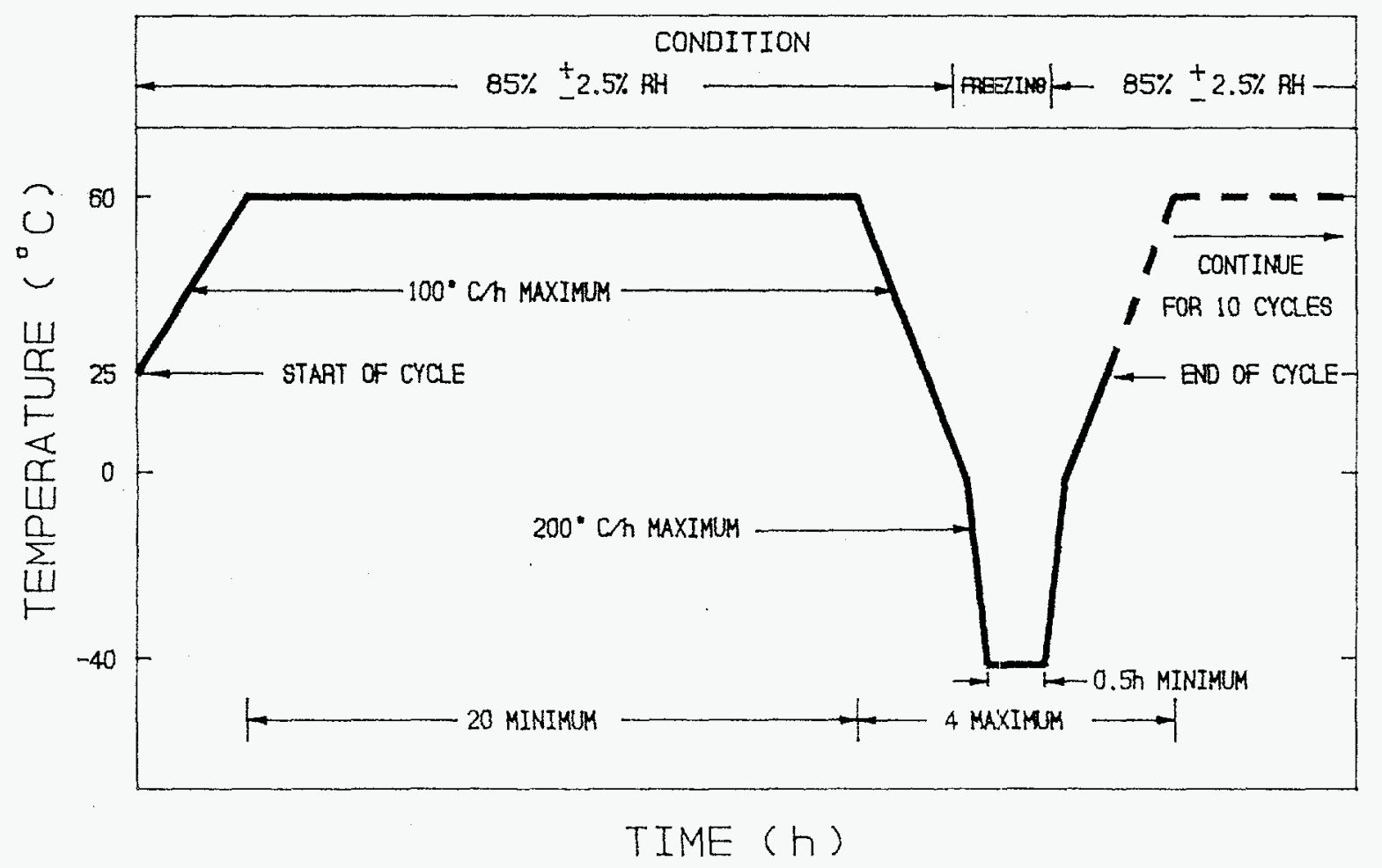

Figure 5.2 Humidity/Freeze Cycle for Module. 

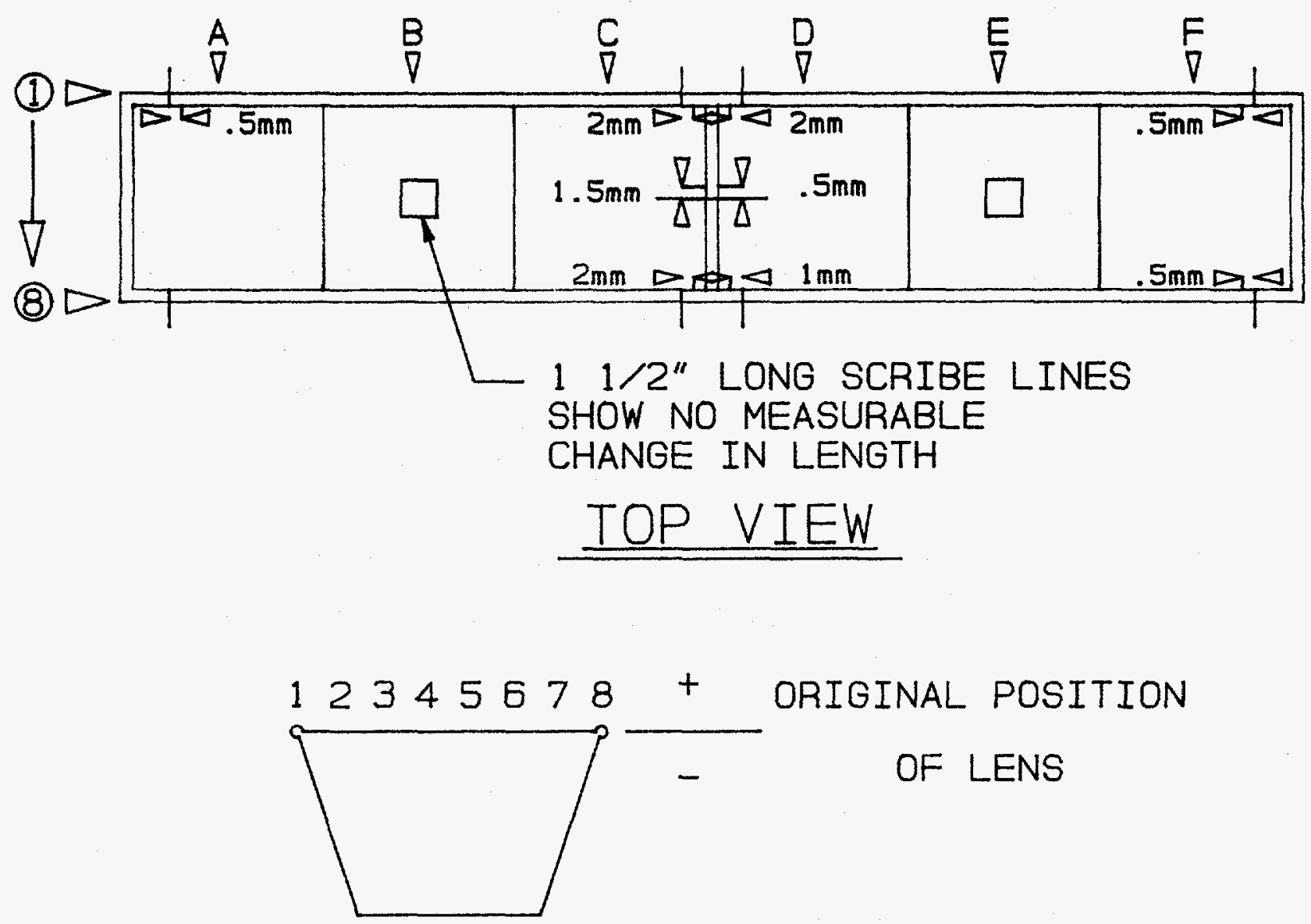

END VIEW

\begin{tabular}{cccccccc}
\multicolumn{7}{c}{ RELATIVE DISPLACEMENT } \\
EDGE (1) & -0.5 & 0 & -0.5 & -0.5 & 0 & -0.5 \\
(2) & -4.0 & +0.5 & -5.0 & -5.0 & 0 & -4.0 \\
(3) & -5.5 & +2.0 & -6.0 & -6.0 & +1.0 & -5.5 \\
(4) & -5.5 & +3.0 & -6.5 & -6.5 & +2.0 & -5.5 \\
(5) & -6.0 & +2.0 & -6.5 & -6.0 & +2.5 & -5.5 \\
(3) & -5.5 & 0 & -6.0 & -5.5 & 0 & -5.0 \\
(7) & -4.0 & -1.5 & -4.5 & -4.0 & -1.0 & -3.0 \\
EDGE (8) & -0.5 & 0 & -0.5 & -0.5 & 0 & -0.5
\end{tabular}

Figure 5.3 Displacements of "Mock" Lens after Humidity/ Freeze Cycles. 
After the module came out of the humidity/freeze cycling chamber, it was subjected to the rain test. For the rain test, the module was positioned on the tester with the long axis in the N-S direction and with the north end of the module raised about $30^{\circ}$. The testing was performed by placing the module in three different orientations, lens up, lens west, and lens down. Simulated rain sprayed on the module for one hour in each orientation. Table 5.1 summarizes the test results. In the lens-up position, no water leaked into the module. In the lens-west position, about a tablespoon of water collected in the lowest point of the module. The module was left for three days to dry out. In the lens-down orientation, about a teaspoon of water accumulated in the bottom of the module, next to the acrylic sheet. The entry point(s) for the water was not apparent for either of the leaks.

To determine the possible point(s) of the leak(s), the rubber vent plugs in the module were removed and the holes sealed with tape. The rain test was repeated in the lens west orientation. No water was observed in the module after the test. The rubber vent plugs were reinstalled and the rain test performed again. Again, no leakage was observed.

Also, the results of the rain tests are summarized in Table 5.1.

\begin{tabular}{|c|c|c|c|}
\hline \multicolumn{4}{|c|}{$\begin{array}{l}\text { Table } 5.1 \\
\text { Rain Test Leaks After Humidity/Freeze Cycle }\end{array}$} \\
\hline Lens Orientation & Upwards & West: & Down \\
\hline Test 1 & None & Tablespoon & Teaspoon \\
\hline Test 2 (No Vent) & None & None & None \\
\hline Test 3 & None & None & None \\
\hline
\end{tabular}

The varying wind speeds and directions could account for the different results obtained above. The differing wind conditions for the various rain tests are documented in Table 5.2.

\begin{tabular}{|cccc|}
\hline & \multicolumn{2}{c|}{$\begin{array}{c}\text { Table 5.2 } \\
\text { Wind Speed \& Direction } \\
\text { SKI Module Rain Test } \\
\text { Wind }\end{array}$} \\
& & $\begin{array}{c}\text { Wind } \\
\text { Speed }\end{array}$ & Wind \\
& Module & Direction \\
Test Set & Orientation & $1.5-1.8$ & S-W NW \\
2 & Lens Up & $1.0-1.5$ & S SW-W NW \\
2 & Lens W & 2 & S SW-MW \\
2 & Lens Dn & $1.5-1.8$ & S SW-N NW \\
3 & Lens W & $1.6-2.2$ & S-W NW \\
3 & Lens Dn & & \\
\hline
\end{tabular}


Based on the results presented in Table 5.1, it is difficult to obtain any relationship between wind conditions and leakage. Also from Table 5.2, it may be noted that the rain test was not repeatable for the small leakage observed in Test 1 . It was concluded by Sandia that a small leakage point exists at some location in the module. As per the current qualification requirements, the module passes the rain test after humidity/freeze cycling because of the small quantity of leakage. 


\subsection{Conclusions and Recommendations}

A low-cost, commercial 282-sun concentrator was designed under this photovoltaic concentrator development project. Many of the components for the module were designed for performance, survivability, low cost, and high-volume manufacturing. Most of the components used for the fabrication of the cell assemblies and the module housing were fabricated in the prototype shop at SKI. Two key components, the PV cell and the point-focus Fresnel lens, were bought from vendors. The components that were designed, developed,and fabricated in small quantities include the top contact, bottom contact, heat spreader, secondary optical element, interconnects, diode assemblies, end caps, module housing and partition clip. The edge clip was extruded by an outside vendor. The lamination of the dielectric film inside the aluminum housing was performed at SKI.

The cell assemblies were fabricated at SKI and subjected to the various qualification requirements of Sandia. They passed all of the initial electrical characterization and high-potential tests. Under environmental cycling, the only bond that failed was the PV cell-to-heat spreader interface. The other components (top contact, bottom contact, SOE) survived the thermal cycling tests.

The cell assemblies were designed to be mounted onto the receiver section with a thermally conductive RTV. This geometry was subjected to thermal cycling and humidity/freeze tests. There was no delamination of this bond nor was there electrical breakdown when the assemblies were subjected to the hi-pot test.

A mock module was built to investigate the lens mounting seal under humidity/freeze cycling. The module was next subjected to the rain tests. The module survived the humidity/freeze cycles and also passed the rain tests.

Availability of $2 \times 2$ injection-molded lens parquet is important to accurately evaluate the module's survivability to environmental conditions. Also, the current method used by SKI to bond the individual lenses is expensive and has a high rejection rate of the parquets.

Various production techniques for the components should be carefully evaluated to minimize the cost of the module. Also, the components must be designed not only for performance, but also for manufacturing. No cost studies were performed because it was too early in the product development phase to obtain realistic high-volume costs for the components and fabrication labor. We believe that once a few prototype modules have been fabricated, it will be appropriate to perform cost studies.

Functional and complete prototype modules were not built under this contract because of the various developmental issues, and schedule and cost constraints. Significant progress was made on the design, fabrication, and testing of most of the components. 
The work presented in this report will be continued under the Concentrator Initiative Contract. Numerous modules will be fabricated and tested under the Concentrator Initiative Program. 


\subsection{References}

1. E. H. Richards, "Sandia Baseline III Photovoltaic Concentrator Module," 20th IEEE Photovoltaic Specialists Conference, Las Vegas, Nevada, September 1988.

2. C. J. Chiang and E. H. Richards, "Reliability Research and Cell Assembly Design for Photovoltaic Concentrator Modules," 19th IEEE Photovoltaic Specialists Conference, New Orleans, LA, May 1987.

3. R. S. Barlow and E. H. Richards, Qualification Tests for Photovoltaic Concentrator Cell Assemblies and Modules, SAND86-2743, Albuquerque, NM: Sandia National Laboratories, 1988.

4. C. B. Stillwell, "Evaluation Report, SKI Cell Assemblies," Sandia Contract 05-4239D, Photovoltaic Technology Research Division 6224, Sandia National Laboratory, Albuquerque, NM, February 1991.

5. Letter to Shabbar T. Saifee from Charlie B. Stillwell, dated February 25, 1991. 


\section{APPENDIX A}

SUBJECT:

SPECIFICATION FOR HIGH CONCENTRATION SILICON CONCENTRATOR SOLAR CELL: P/N 60-7046

1.0 MANUFACTURER: APPLIED SOLAR ENERGY CORPORATION

1.1 SCOPE

This specification defines design, construction and testing of silicon concentrator solar cell. This concentrator solar cell is also referred to as the cell.

2.0 APPLICABLE DOCUMENTS AND DRAWINGS

2.1 ASEC P/N 60-7046

2.2 ASEC Drawing A-204323 High Concentration Si Concentrator Cell

3.0 CELL DESIGN

3.1 The cell is a $\mathrm{N}+/ \mathrm{P} / \mathrm{P}+$ configuration.

3.2 Starting Materials:

3.2.1 Single crystal float zone (FZ) silicon.

3.2.2 P-type silicon, boron doped.

$3.2 .3 \quad .17-.23 \mathrm{ohm}-\mathrm{cm}$ resistivity.

3.2.4 100 orientation.

$3.2 .5 .008 \pm .002$ inch thick.

3.3 The $\mathrm{N}+$ junction is formed by phosphorus diffusion.

3.4 The $\mathrm{P}+$ back surface layer is formed by alloying of evaporated layer of aluminum.

3.5 The gridline pattern and dimensions are determined by computer aided design to optimize cell performance for high concentration sunlight.

3.6 The front contact (N-contact) and gridline metals are conventional evaporated Ti-Pd$\mathrm{Ag}$, chosen because of the known overall high performance and high reliability. The silver thickness for front contact and gridlines are 7 to $10 \mathrm{um}$.

3.7 The back contact (P-contact) of the solar cell is conventional evaporated Al-Ti-Pd-Ag. The silver thickness for back contact is 3 to $5 \mathrm{um}$.

3.8 The active area is coated with antireflective coating of titanium dioxide and aluminum oxide optimized for AM1 sunlight spectrum.

3.9 The contact metals and AR coating will be sintered to ensure good adhesion. 


\subsection{MECHANICAL SPECIFICATIONS}

4.1 Drawing: ASEC A-204323

4.2 Size: $.542 \times .542$ inch overall, $.406 \times .406$ active area.

4.3 Thickness: $.008 \pm .002$ inch.

4.4 Any evidence of peeling or lifting of contact metals due to poor contact adhesion is considered a reject.

4.5 A maximum contact voids of $2 \%$ is allowed for both contacts.

4.6 Minor gridline discontinuities are not considered as a reject as long as the electrical requirements are met.

4.7 Maximum allowable edge chips and nicks are .020 inch in depth and .100 inch in length.

4.8 Maximum allowable corner chips or nicks are .150 inch on the hypotenuse.

4.9 Voids in AR coatings are not rejects as long as electrical requirements are met.

\subsection{ELECTRICAL SPECIFICATION}

5.1 The minimum cell efficiency is $16 \%$ at 385 suns concentration and $28^{\circ} \mathrm{C} \pm 2^{\circ} \mathrm{C}$.

5.2 The minimum average cell efficiency for each shipping lot is $17.0 \%$ at 385 suns concentration and $28^{\circ} \mathrm{C} \pm 2^{\circ} \mathrm{C}$.

5.3 The solar cells are tested at 385 times solar constant (AM1) and $28 \pm 2{ }^{\circ} \mathrm{C}$. The test voltage is $600 \pm 2 \mathrm{mV}$. The solar cells are grouped into the following groupings:

$\begin{array}{ccc}\text { Group No. } & \begin{array}{c}\text { Min. Current At } \\ 600 \mathrm{mV}(\mathrm{AMP})\end{array} & \begin{array}{c}\text { Min. Efficiency } \\ (\%)\end{array} \\ 1 & 10.9 & 16.0 \\ 2 & 11.2 & 16.4 \\ 3 & 11.5 & 16.8 \\ 4 & 11.8 & 17.3 \\ 5 & 12.1 & 17.7 \\ 6 & 12.4 & 18.2 \\ 7 & 12.7 & 18.6 \\ 8 & 13.0 & 19.0\end{array}$

5.4 The minimum output current for the shipping lot is 10.9 Amperes at $600 \mathrm{mV}$. The average shipping lot is 11.6 Amperes at $600 \mathrm{mV}$. 


\subsection{QUALITY ASSURANCE PROVISIONS}

6.1 Responsibility of Inspection

ASEC is responsible for the performance of the mechanical inspection and electrical testing as specified herein in paragraphs 4.0, 5.3 and 5.4.

6.2 Mechanical Inspection

Each cell is inspected to meet the mechanical specifications per paragraph 4.0.

6.3 Electrical Performance

The electrical performance of each cell is tested to assure compliance with cell electrical specifications per paragraph 5.3 and 5.4.

\subsection{SHIPPING}

7.1 Solar cell will be packed in containers which are adequate to protect the cells from mechanical damage. Each container will contain solar cells of the same electrical groupings. Cells shall be packaged in a hermetically sealed container with desiccant and a relative humidity indicator for shipment. 


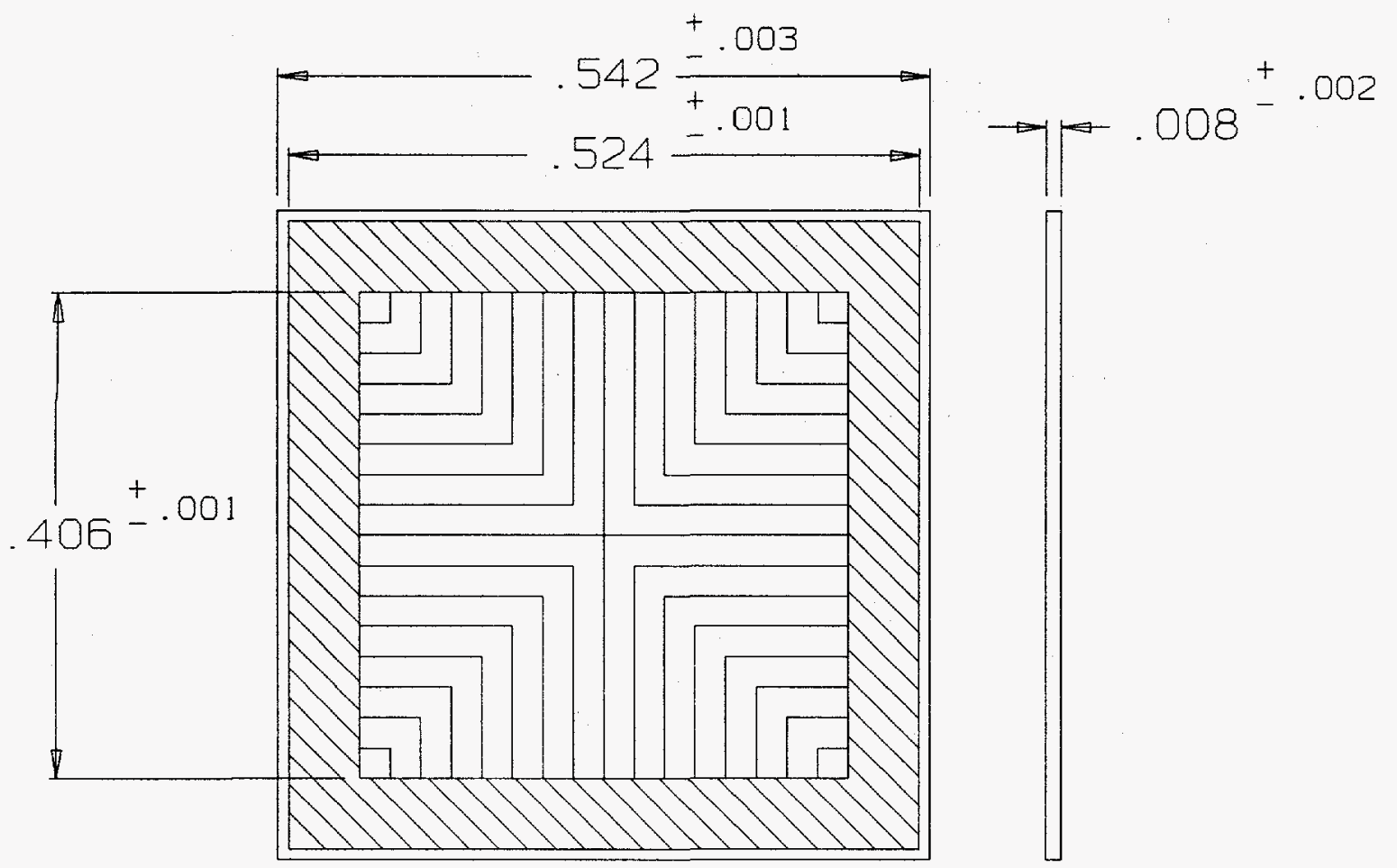

NOTE:

1.0 The solar cell is designed for high concentration sunlight application.

2.0 The solar cell is $\mathrm{N}+\mathrm{PP}+$ silicon solar cell made from high quality, float zone (FZ) Ptype silicon with substrate resistivity of $0.17-0.23 \mathrm{Ohm}$.

3.0 The N-contact (front) is vacuum deposited titanium-palladium-silver. The P-contact (back) is vacuum deposited of aluminum-titanium-palladium-silver. The silver thickness on the gridline and front contact is 7 to $10 \mathrm{um}$. The sillver thickness for the Pcontact is 3 to 5 um.

4.0 The active area is coated with antireflective coating of titanium, dioxide, and aluminum oxide optimized for AM1 solar spectrum. 
Distribution:

Alpha Solarco (2)

Attn: Edward Schmidt

Donald Carroll

11534 Gondola Drive

Cincinnati, OH 45241

Arizona Public Service Co.

Attn: Thomas Lepley

Mail Stop 9110

Post office Box 53999

Phoenix, AZ 85072-3999

Arizona Public Service Co.

Star Facility

Attn: Peter Eckert

1500 East University

Tempe, AZ 85281

Arizona State University

College of Engineering and

Applied Science

Attn: Robert Hammond

Tempe, AZ 85287-5806

Bechtel National, Inc.

Attn: Walter J. Stolte

Post office Box 3965

Mail Stop 50/15/D17

San Francisco, CA 94119-3965

Black and Veatch

Attn: Kevin Kerschen

Post Office Box 8405

Kansas City, MO 64114

Boeing Electronics Company (2)

Attn: Mark Kuryla

Dr. Lewis Fraas

P. 0. Box 24969, MS 9Z-80

Seattle, WA 98124-6269

Mr. Clement Chiang

GE Astrospace, MS NP-2K

100 Nassau Park Boulevard

West Windsor, NJ 08543-800

City of Austin

Electric Department

Attn: John E. Hoffner

Post Office Box 1088

Austin, TX 78767
Cummings Engineering

Attn: Richard Cummings

323 Andover Street

Wilmington, MA 01887

Daystar

Attn: Vern Risser

4200 South Research Drive

Las Cruces, NM 88003

Endecon

Attn: Chuck Whitaker

3401 Crow Canyon Road

Suite 253

San Ramon, CA 94583

ENTECH

Attn: Mark O'Neill

P. O. Box 612246

DFW Airport, TX 75261

EPRI (3)

Attn: Frank Dostalek John Bigger

Frank Goodman

P. O. Box 10412

Palo Alto, CA 94303

James Associates

Attn: Larry James

7329 Meadow Court

Boulder, CO 80301

Jet Propulsion Lab (3)

Attn: Russ Sugimura

Ron Ross

Gordon Mon

M/S 157-102

4800 Oak Grove Drive

Pasadena, CA 91109

Midway Labs

Attn: Paul Collard

2255 East 75th Street

Chicago, IL 60649

NREL (2)

Attn: Dick DeBlasio

Laxmi Mrig

1617 Cole Boulevard

Golden, CO 80401 
NREL Library

1617 Cole Boulevard

Golden, CO 80401

Pacific Gas and Electric (4)

Attn: Steve Hester Joe Iannucci

Howard Wenger

Tammie Candelaria

3400 Crow Canyon Road

San Ramon, CA 94583

Siemens Solar, Inc.

Attn: Kim Mitche11

Post Office Box 6032

Camarillo, CA 93011

Solar Engineering Applications Attn: Neil Kaminar 305 North Mathilda Avenue Sunnyvale, CA 94086

Solar Kinetics, Inc. Attn: Shabbar Saifee

P. O. Box 540636

Dallas, TX 75354-0636

Solarex Corporation

Attn: John Wohlgemuth

630 Solarex Court

Frederick, MD 20701

Southern California Edison

Attn: Nick Patapoff

6090 Irwindale Avenue

Irwindale, CA 91702

Southern Electric Int'1.

Georgia Power Research Center

Attn: Edward King

62 Lake Mirror Road, Bldg. 3

Forest Park, GA 30050

SunPower Corp. (3)

Attn: Richard Swanson

Charles Tilford

Ron Sinton

435 Indio Way

Suite 100

Sunnyvale, CA 94086
SWTDI

Attn: Steven Durand

Box 30001, Dept. 3SOL

Las Cruces, NM 88003-0001

Texas Southern University

Attn: v. S. Murty, Physics

3100 Cleburne Avenue

Houston, TX 77004

3M Company

Attn: Paul Jaster, 225-2N-06

3M Center

St. Paul, MN 55144

US Department of Energy

Attn: James Rannels, CE-131

Forrestal Building

1000 Independence Avenue, SW

Washington, DC 20585

VS, Inc.

Attn: Jan Werthen

611 Hansen Way, MS K-124

Palo Alto, CA 94303

Wattsun

Attn: John Doherty

Post Office Box 751

Albuquerque, NM 87103

University of New South Wales

Attn: Dr. Martin Green

School of Electrical

Engineering

Post Office Box One

Kensington, NSW 2033

AUSTRALIA

Canada Centre for Mineral and Energy Technology

Attn: Allen Carpenter

2395 Speakman Drive

Mississauga, Ontario L.5K $1 \mathrm{~B} 3$

CANADA 
Commission of the European

Communities (2)

Joint Research Centre, ESTI

Attn: H. Ossenbrink

TP 450

James Bishop

21020 Ispra, VA

ITALY

Fraunhofer Institute for Solar

Energie Systeme

Attn: Klaus Heidler

Oltmannsstrasse 22

D-7800 Freiburg

GERMANY

Instituto de Energia Solar

Ciudad Universitaria, $s / n$

Attn: Antonio Luque

ETSI Telecomunicacion (UPM)

28040 Madrid

SPAIN

1841

D. L. Sharp

6200

B. W. Marshall

6202

G. J. Jones

6213

T. C. Bickel

6213

P. A. Basore

6213

T. D. Hund

6213

A. B. Maish

6213

J. R. Woodworth

6218

D. E. Hasti

6218

6219

E. H. Richards

6219

6219

J. E. Cannon

D. L. King

6219 K. D. McAllister

6219 M. L. Whipple (10)

7141 Technical Library (5)

7151 Technical Pubs. (1)

7613-2 Document Processing for DOE/OSTI (10)

8523-2 Central Tech. Files (1) 